\title{
Acid-Promoted Cyclization Reactions of Tetrahydroindolinones. Model Studies for Possible Application in a Synthesis of Selaginoidine
}

\author{
Mickea D. Rose ${ }^{\#}$, Michael P. Cassidy, Paitoon Rashatasakhon, and Albert Padwa \\ Department of Chemistry, Emory University, Atlanta, Georgia 30322, chemap@emory.edu
}

\begin{abstract}
The synthesis of various substituted bicyclic lactams by an acid-induced Pictet-Spengler reaction of tetrahydroindolinones bearing tethered heteroaromatic rings is presented. The outcome of the cyclization depends on the position of the furan tether, tether length, nature of the tethered heteroaromatic ring and the substituent group present on the 5-position of the tethered heteroaryl group. A one-pot procedure was developed to efficiently prepare tetrahydroindolinones containing tethered furan rings. In a typical example, the reaction of furanyl azide 26 with $n$ - $\mathrm{Bu}_{3} \mathrm{P}$ delivered iminophosphorane $\mathbf{2 7}$, which was allowed to react with a 1 -alkyl-(2-oxocyclohexyl)acetic acid to provide the desired furanyl substituted tetrahydroindolinone system 29. Treatment of $\mathbf{2 9}$ with trifluoroacetic acid afforded the tetracyclic lactam skeleton $\mathbf{3 0}$ found in the alkaloid ( \pm )-selaginoidine.
\end{abstract}

\section{Introduction}

The Pictet-Spengler reaction corresponds to an acid-catalyzed intramolecular cyclization of a 2 -arylethylimine. ${ }^{1-3}$ This process is routinely used for the synthesis of tetrahydroisoquinolines and tetrahydro- $\beta$-carboline ring systems, which are present in numerous natural and synthetic organic compounds possessing biological activity. ${ }^{4}$ Although the Pictet-Spengler reaction has long been believed to require electron-rich aromatics such as indoles or aryl rings substituted with strongly electron-donating substituents such as hydroxy or alkoxy groups, ${ }^{5}$ superacid catalysts do enable the cyclization of unactivated imines of type 1 to give 1 -substituted 1,2,3,4tetrahydroisoquinolines $2 .{ }^{6}$ A number of diastereoselective substrate-controlled PictetSpengler cyclizations have also been developed leading to useful chiral building blocks for alkaloid synthesis. ${ }^{7}$ Recently, Jacobsen ${ }^{8}$ and List ${ }^{9}$ have independently reported examples of highly enantioselective catalytic Pictet-Spengler reactions providing ready access to a range of substituted tetrahydro- $\beta$-carbolines in high enantiomeric excess.

In an earlier report from our laboratory, we described a convenient synthesis of variously substituted octahydroindolo[7a,1a]isoquinolines by an acid-induced Pictet-Spengler reaction of tetrahydroindolinones bearing tethered phenethyl groups (Scheme 2). ${ }^{10}$ A related NBSpromoted intramolecular electrophilic aromatic substitution reaction of 1 -[2-(3,4dimethoxyphenyl)ethyl]-1,4,5,6-tetrahydroindolinone (3b) was also used to assemble the tetracyclic core of the erythrinone skeleton. The resulting cyclized product 5 was transformed into the erythrina alkaloid $( \pm$ )-erysotramidine $(\mathbf{6})$ in three additional steps.

\footnotetext{
Correspondence to: Albert Padwa.

\#NIH Ruth L. Kirchstein Predoctoral Fellow.
} 
The erythrina and related homoerythrina family of alkaloids constitute a large class of structurally diverse natural products that have received considerable attention over the past few decades. ${ }^{11}$ Members of the erythrina and homoerythrina family possess curare-like activity, and the alkaloidal extracts have been used extensively in indigenous medicine. ${ }^{12}$ Each of these alkaloid groups are generally classified into two sets according to their structural features, ${ }^{13}$ those whose D-rings are aromatic (e.g. 3-demethoxyerythratidinone (7) and schelhammerine (8)) and the others whose D-rings are nonbenzenoid (e.g. phellibiline (9) and selaginoidine (10)). ${ }^{14}$ Many different approaches have been employed for the synthesis of these alkaloids. ${ }^{15-17}$

On the basis of our earlier studies, ${ }^{10}$ we felt that a Pictet-Spengler reaction of a suitably substituted tetrahydroindolinone precursor might allow for a facile entry to the tetracyclic core of selaginoidine (10), a unique homoerythrina nonbenzenoid alkaloid isolated from the taxodeaceous plant Athrotaxis selaginoides. ${ }^{18}$ The formation of the homoerythrina skeleton of $\mathbf{1 0}$ was envisioned to come about from a Pictet-Spengler cyclization of furanyl tetrahydroindolinone 11. A convenient way to construct 11 would involve condensation of an appropriate furanyl amine such as $\mathbf{1 3}$ with a 1-substituted-(2-oxocyclohexyl)acetic acid derivative (i.e., 12) under Dean-Stark conditions (Scheme 3). In this paper, we describe an account of our efforts to synthesize the homoerythrina skeleton using the Pictet-Spengler cyclization of tetrahydroindolinones containing tethered heteroaromatic rings.

\section{Results and Discussion}

As a prelude to the synthesis of selaginoidine (10), we first set out to evaluate the PictetSpengler reaction of several tetrahydroindolinones containing tethered furans in order to test the viability of our design as well as to determine the scope and generality of the cyclization. With this in mind, we first studied the cyclization of tetrahydroindolinone 16. ${ }^{19}$ Condensation of (1-methyl-2-oxocyclohexyl)acetic acid (14) with 2-furan-2-ylethylamine (15) under DeanStark conditions in xylene at $160^{\circ} \mathrm{C}$ for $1 \mathrm{~h}$ afforded the desired bicyclic lactam 16 in $65 \%$ yield. Treatment of $\mathbf{1 6}$ with trifluoroacetic acid produced the tetracyclic substituted lactam 18 in 78\% yield (Scheme 4). The formation of a single lactam diastereomer is the result of the stereoelectronic preference for axial attack by the furan ring on the $N$-acyliminium ion $17^{20}$ from the least hindered side. ${ }^{21}$ This cyclization is especially noteworthy considering that none of the previously reported syntheses of the nonbenzenoid erythrina class of alkaloids have employed this strategy of assemblage. ${ }^{22}$

To demonstrate that this methodology could also be used for $\beta$-phenethylamine pharmacophores ${ }^{23}$ possessing the homoerythrina skeleton, the homologous furan $\mathbf{1 9}(\mathrm{n}=2)$ was treated with keto acid $\mathbf{1 4}$ and the resulting tetrahydroindolinone $\mathbf{2 0}$ was subjected to the acid-catalyzed cyclization conditions (Scheme 5). Interestingly, the only product isolated in $54 \%$ yield corresponded to the novel dimeric furanyl bis-lactam $\mathbf{2 1}$ which is derived by bimolecular trapping of the $\mathrm{N}$-acyliminium ion at the more activated 5-position of the furan ring.

At this point we reasoned that by incorporating a substituent at the 5-position of the furan ring we would be able to suppress the undesired dimerization reaction. With this in mind, we prepared tetrahydroindolinone $\mathbf{2 4}$ containing a methyl group at the 5-position of the furan ring by the condensation of 3-(5-methyl-furan-2-yl)propan-1-amine (22) with benzyl 1-(2ethoxy-2-oxoethyl)-2-oxocyclo-hexanecarboxylate (23) which gave $\mathbf{2 4}$ in $62 \%$ yield. Gratifyingly, the reaction of $\mathbf{2 4}$ with TFA at $25{ }^{\circ} \mathrm{C}$ afforded bicyclic lactam $\mathbf{2 5}$ in $95 \%$ yield, where cyclization now occurred at the 3-position of the furan ring as a consequence of the presence of the methyl group which blocks the dimerization pathway (Scheme 6). 
We also investigated the acid catalyzed cyclization of the related tetrahydroindolinone 29. Our first attempts to synthesize 29 involved the reaction of 2-(3-aminopropyl)-5-ethylfuran with ketoacid 14. In our hands, the reduction of azides such as $\mathbf{2 6}$ to the required primary amine sometimes proved to be problematic. Likewise, the Staudinger reaction 24 using the iminophosphorane $\mathbf{2 7}$ derived from azide $\mathbf{2 6}$ also proved troublesome, as we could only obtain the corresponding amine as an impure oil in low yield. Iminophosphoranes were first prepared at the beginning of the last century by Staudinger and have become extremely useful reagents for the construction of nitrogen containing heterocycles. ${ }^{24}$ The aza-Wittig reaction corresponds to the nitrogen analogue of the Wittig olefination process and involves the reaction of an iminophosphorane with a carbonyl group. The reaction has been used to prepare various imines and its synthetic relevance has been summarized in several review articles. ${ }^{25}$ The intramolecular version of this reaction has drawn considerable attention in recent years because of its high potential for heterocyclic synthesis. ${ }^{26}$ Since we were having some difficulty converting azide $\mathbf{2 6}$ into the corresponding amine for subsequent condensation with ketoacid $\mathbf{1 4}$, we wondered whether it might be possible to use azide $\mathbf{2 6}$ directly without the intervention of the amine. Thus, an aza-Wittig type reaction of iminophosphorane 27 with ketoacid 14 should generate $\mathbf{2 8}$, which could be expected to rapidly cyclize and furnish the desired tetrahydroindolinone system $\mathbf{2 9}$ (Scheme 7). Indeed, this proved to be the case, especially when microwave technology was applied to the condensation reaction. Treating a sample of $\mathbf{2 9}$ with trifluoroacetic acid afforded bicyclic lactam 30 in $96 \%$ yield. In this case cyclization occurred at the 3-position of the furan ring, again as a consequence of the presence of the ethyl group, which blocks the dimerization route. Thus, by using this methodology we were able to construct the seven-membered $\mathrm{C}$ ring of model compounds $\mathbf{2 5}$ and $\mathbf{3 0}$ which contain the required tetracyclic furan-type skeleton of selaginoidine (10).

A series of additional experiments showed that this electrophilic-induced cyclization succeeds with a variety of substrates containing tethered heteroaromatic rings. Thus, we were pleased to find that the analogous (3-furan-2-yl)ethyl substituted tetrahydroindolinone $\mathbf{3 1}$ also underwent a related acid-induced cyclization to give the tetracyclic substituted lactam $\mathbf{3 2}$ in $98 \%$ yield (Scheme 8 ). As all of the previous examples involved furanyl $\pi$-bond cyclizations, we decided to study several tetrahydroindolinones which contain other tethered five-ring heterocycles. We found that treatment of the thiophen-3-yl substituted system $\mathbf{3 3}$ with trifluoroacetic acid at $25{ }^{\circ} \mathrm{C}$ for $4 \mathrm{~h}$ afforded the closely related tetracyclic lactam 34 in $73 \%$ yield (Scheme 8). However, in order to induce cyclization of the isomeric thiophen-2-yl substituted system $\mathbf{3 5}$, it was necessary to heat this compound at $90{ }^{\circ} \mathrm{C}$ using polyphosphoric acid as solvent for $12 \mathrm{~h}$ and the resulting product $\mathbf{3 6}$ was only isolated in $33 \%$ yield. As is the case with other five-membered heterocycles, electrophilic substitution at the 2-position of the ring is strongly favored over the 3-position and this factor nicely accommodates the marked difference in the rate of cyclization of $\mathbf{3 3} v s$. 35 . Annulative ring cyclization of the pyrrolo-2yl substituted system also occurred producing the tetracyclic lactam 38 in $70 \%$ yield. In this case, it was not possible to isolate tetrahydroindolinone $\mathbf{3 7}$ as it rapidly cyclized to $\mathbf{3 8}$ under the conditions used for its preparation.

Related cyclization reactions were also observed to occur with the analogous indolyl substituted amines 39 and $\mathbf{4 1}$ (Scheme 9). The cyclized products $\mathbf{4 0}$ and $\mathbf{4 2}$ were easily obtained from the condensation of keto acid $\mathbf{1 4}$ with either of the primary indolylamines. The condensation reaction was best carried out under microwave conditions at $180^{\circ} \mathrm{C}$. The expected tetrahydroindolinones were not detected as they readily underwent cyclization to give the tetracyclic lactams $\mathbf{4 0}$ and $\mathbf{4 2}$ in $85 \%$ and $90 \%$ yield, respectively. These two additional examples nicely demonstrate the facility with which the acid-induced cyclization cascade occurs using a variety of cyclic enamido lactams containing tethered heteroaromatic rings. 
Earlier work in our laboratory has shown that the Pummerer reaction followed by a $\pi$ cyclization represents an effective and general method for the preparation of many diverse azapolycyclic skeletons. ${ }^{27}$ Since the combination of a Pummerer/Mannich cyclization sequence offers unique opportunities for the assemblage of complex target molecules, ${ }^{28}$ we decided to study the acid-induced cyclization of enamides $46(n=1)$ and $47(n=2)$ to determine whether these systems could also be used to assemble the core skeleton of the erythrina/homoerythrina family of alkaloids. Furanyl azide $\mathbf{4 3}$ was easily converted into the desired enamide sulfide (i.e., 44) following the azide/iminophosphorane/ethylthioacetyl chloride protocol already established (Scheme 10). A subsequent sodium periodate oxidation afforded sulfoxide 46, which on treatment with trifluoroacetic anhydride in the presence of trifluoroacetic acid furnished the tetracyclic lactam $\mathbf{4 8}$ in $76 \%$ yield as the exclusive product. The preferential formation of $\mathbf{4 8}$ is consistent with our earlier stereochemical observations, ${ }^{29}$ suggesting that a $4 \pi$-Nazarov type electrocyclization 30 controls the direction of closure from the $\alpha$ acylthionium ion intermediate. The Pictet-Spengler step involves attack of the proximal furanyl ring from the less hindered side of the iminium ion.

To demonstrate that this methodology could also be used for assembling the homoerythrina skeleton, the homologous furanyl sulfoxide $\mathbf{4 7}$ was subjected to the acid catalyzed cyclization conditions (Scheme 10). The major product isolated (40\%) corresponded to the cyclized lactam 49. Presumably, the lower yield of product is related to the entropically more demanding sevenmembered ring cyclization onto the resulting $N$-acyliminium ion formed from the initial Pummerer reaction. We also attempted to prepare the simpler seven-membered tetracyclic lactam $\mathbf{5 2}$ by subjecting sulfoxide $\mathbf{5 0}$ to the Pummerer cyclization conditions. Our hope was that it would be possible to induce a tandem Pummerer/ $N$-acyliminium ion cascade and convert $\mathbf{5 0}$ directly into $\mathbf{5 2}$ as shown in Scheme 11. Toward this end, a sample of $\mathbf{5 0}$ was heated in benzene in the presence of 10-camphorsulfonic acid and this resulted in the formation of the Pummerer cyclized lactam 51 in 70\% yield. Unfortunately, all of our further efforts to prepare 52 from 51 only provided a complex mixture of products and we eventually had to abandon further cyclization studies with this system.

An alternative approach that we explored in an attempt to form the key seven-membered ring of selaginoidine (10) was to use either a Heck or radical-induced cyclization of a model 3bromo-furanyl substituted tetrahydroindoline such as 56. The synthesis of $\mathbf{5 6}$ was carried out by reacting azide 53 with tributylphosphine at $25^{\circ} \mathrm{C}$. Addition of ketoacid 14 to iminophosphorane $\mathbf{5 4}$ followed by mircrowave irradiation gave the desired enamido lactam 56 in $63 \%$ yield presumably via the intermediacy of imine 55 (Scheme 12). Unfortunately, all of our efforts to induce either a Heck or radical cyclization of $\mathbf{5 6}$ failed to produce the desired product and only dark tarry oils were obtained. Despite our best efforts to vary the experimental conditions, no detectable quantities of a cyclized product derived from $\mathbf{5 6}$ could be obtained.

Since the Heck/radical cyclization route proved to be unfeasible, we decided to reexamine the acid-catalyzed cyclization of our model system (i.e., 24). The simplest readjustment would be to add a 1,3-dioxolanyl group at the 5-position of the tetrahydroindolinone ring. In fact, this addition would create a more accurate model system (i.e., 58), since the target homoerythrina alkaloid selaginoidine possesses a methoxy substituent at the 10-position of the A-ring which we assumed could eventually be derived from the ketal group located at the $\mathrm{C}(11)$ carbon atom. The retrosynthetic plan we had in mind is outlined in Scheme 13. To this end, keto ester 57 was prepared and condensed with furanyl amine $\mathbf{2 2}$ to provide tetrahydroindolinone $\mathbf{5 8}$ in $80 \%$ yield. With the bicyclic system now functionalized, we explored the conversion of $\mathbf{5 8}$ into 59. However, all of our efforts to achieve this cyclization using a variety of acidic conditions failed. Repeated trials simply resulted in the hydrolysis of the ketal functionality to the corresponding ketone $\mathbf{6 1}$ or else gave rise to the ring opened 1,4-dione $\mathbf{6 0}$ derived from hydrolysis of the furan ring. 
The problem with this approach appears to be that generation of the required $\mathrm{N}$-acyliminium ion by protonation of $\mathbf{5 8}$ was simply too slow relative to the hydrolysis of either the ketal or furanyl functionalities. Based on the knowledge that hydroxy amides such as $\mathbf{6 4}$ are more reactive towards protonation than enamides of type $\mathbf{5 8},{ }^{20}$ we next examined the TFA promoted cyclization of bicyclic lactam 64. As shown in Scheme 14, our synthesis of 64 starts by treating 1,4-dioxaspiro[4.5]decan-8-one (62) with LDA at $-78{ }^{\circ} \mathrm{C}$ in THF and allowing the resulting enolate to react with 2-iodo- $N$-(3-(5-methylfuran-2-yl)propyl)acetamide (63). The expected $C$-alkylation reaction occurred smoothly and gave $\mathbf{6 4}$ in $80 \%$ yield. The reaction of $\mathbf{6 4}$ with 2 equiv of TFA in $\mathrm{CH}_{2} \mathrm{Cl}_{2}$ at $25{ }^{\circ} \mathrm{C}$ afforded the desired homoerythrina compound $\mathbf{6 5}$ in $75 \%$ yield which possesses a structure closely related to that of selaginoidine $10 .{ }^{31}$ Further studies using this methodology toward selaginoidine are currently underway and will be described at a future date.

In conclusion, we have developed a general and efficient strategy for the synthesis of the sevenmembered ring skeleton found in selaginoidine. A variety of vinylogous amides and tetrahydroindolinones can be prepared using an $a z a$-Wittig reaction of iminophosphoranes derived from furanyl azides and 1-alkyl-(2-oxocyclohexyl)acetic acids. Intramolecular electrophilic substitution on the furan ring occurs when the tetrahydroindolinone is treated with acid leading to both the six and seven membered C-ring of the erythrina and homoerythrina skeleton. The application of this approach toward other natural product targets is currently under investigation, the results of which will be disclosed in due course.

\section{Experimental Section}

1-(2-Furan-2-yl-ethyl)-3a-methyl-1,3,3a,4,5,6-hexahydroindol-2-one (16) was prepared in $65 \%$ yield from (1-methyl-2-oxo-cyclohexyl)acetic acid ${ }^{32}(\mathbf{1 4})$ and 2-furan-2-ylethylamine $^{33}$; IR (thin film) 2933, 2860, 1674, 1449, and $1072 \mathrm{~cm}^{-1 ; 1} \mathrm{H}-\mathrm{NMR}(400 \mathrm{MHz}$, $\left.\mathrm{CDCl}_{3}\right) \delta 1.12(\mathrm{~s}, 3 \mathrm{H}), 1.51(\mathrm{~m}, 1 \mathrm{H}), 1.73-1.77(\mathrm{~m}, 3 \mathrm{H}), 2.10-2.23(\mathrm{~m}, 4 \mathrm{H}), 2.87(\mathrm{t}, 2 \mathrm{H}, J=$ $7.2 \mathrm{~Hz}), 2.87(\mathrm{~m}, 1 \mathrm{H}), 3.93(\mathrm{~m}, 1 \mathrm{H}), 4.77(\mathrm{t}, 1 \mathrm{H}, J=3.2 \mathrm{~Hz}), 6.06(\mathrm{t}, 1 \mathrm{H}, J=2.4 \mathrm{~Hz}), 6.26(\mathrm{t}$, $1 \mathrm{H}, J=2.0 \mathrm{~Hz})$, and $7.30(\mathrm{t}, 1 \mathrm{H}, J=1.2 \mathrm{~Hz}) ;{ }^{13} \mathrm{C}-\mathrm{NMR}\left(100 \mathrm{MHz}, \mathrm{CDCl}_{3}\right) \delta 18.5,22.8,25.6$, 26.1, 34.1, 36.3, 37.9, 46.4, 97.3, 106.5, 110.4, 141.5, 145.4, 152.7, and 173.8; HRMS Calcd. for $\mathrm{C}_{15} \mathrm{H}_{19} \mathrm{NO}_{2}$ : 245.1416. Found: 245.1411.

\section{8-Methyl-8,8a-cyclohexyl-4,7,8,8a-tetrahydro-5H-3-oxa-5a-aza-as-indacen-6-one (18)}

To a solution of $0.31 \mathrm{~g}(1.3 \mathrm{mmol})$ of hexahydroindolone 16 in $13 \mathrm{~mL}$ of $\mathrm{CH}_{2} \mathrm{Cl}_{2}$ was added trifluoroacetic acid $(0.3 \mathrm{~mL}, 3.8 \mathrm{mmol})$. The mixture was stirred at $\mathrm{rt}$ for $4 \mathrm{~h}$ and the solvent was removed under reduced pressure. The crude product was purified by flash chromatography on silica gel to give $\mathbf{1 8}$ as a colorless oil in 78\% yield; IR (thin film) 2931, 2861, 1687, 1452, 1416 , and $1327 \mathrm{~cm}^{-1 ;}{ }_{1} \mathrm{H}-\mathrm{NMR}\left(400 \mathrm{MHz}, \mathrm{CDCl}_{3}\right) \delta 0.72(\mathrm{~s}, 3 \mathrm{H}), 1.47-1.58(\mathrm{~m}, 4 \mathrm{H}), 1.71-$ $1.78(\mathrm{~m}, 3 \mathrm{H}), 1.90(\mathrm{~d}, 1 \mathrm{H}, J=16.4 \mathrm{~Hz}), 2.10(\mathrm{~m}, 1 \mathrm{H}), 2.70(\mathrm{~m}, 2 \mathrm{H}), 2.79(\mathrm{~d}, 1 \mathrm{H}, J=16.4 \mathrm{~Hz})$, 3.01 (dddd, $1 \mathrm{H}, J=24.4,11.2,6.0$ and $1.6 \mathrm{~Hz}$ ), 4.38 (ddd, $1 \mathrm{H}, J=12.6,6.0$ and $1.6 \mathrm{~Hz}$ ), 6.38 $(\mathrm{d}, 1 \mathrm{H}, J=1.6 \mathrm{~Hz})$, and $7.30(\mathrm{~d}, 1 \mathrm{H}, J=1.6 \mathrm{~Hz}) ;{ }^{13} \mathrm{C}-\mathrm{NMR}\left(100 \mathrm{MHz}, \mathrm{CDCl}_{3}\right) \delta 21.9,22.1$, 23.4, 26.5, 33.7, 33.8, 36.5, 40.2, 42.1, 63.9, 108.5, 119.9, 141.3, 147.8, and 172.3; HRMS Calcd. for $\mathrm{C}_{15} \mathrm{H}_{19} \mathrm{NO}_{2}$ : 245.1416. Found: 245.1406.

1 -(3-Furan-2-yl-propyl)-3a-methyl-1,3,3a,4,5,6-hexahydroindol-2-one (20) was prepared in $81 \%$ yield from keto acid 14 and 3-furan-2-yl-propylamine ${ }^{34}$; IR (thin film) 2935, 2860, 1674,1445 , and $1309 \mathrm{~cm}^{-1 ; 1} \mathrm{H}-\mathrm{NMR}\left(400 \mathrm{MHz}, \mathrm{CDCl}_{3}\right) \delta 1.17(\mathrm{~s}, 3 \mathrm{H}), 1.52(\mathrm{~m}, 1 \mathrm{H}), 1.72$ $1.93(\mathrm{~m}, 5 \mathrm{H}), 2.01-2.23(\mathrm{~m}, 2 \mathrm{H}), 2.25(\mathrm{~s}, 2 \mathrm{H}), 2.63(\mathrm{t}, 2 \mathrm{H}, J=10.2 \mathrm{~Hz}), 3.23$ (ddd, $1 \mathrm{H}, J=$ $18.2,10.0$ and $7.6 \mathrm{~Hz}), 3.67(\mathrm{dt}, 1 \mathrm{H}, J=18.8$ and $10.0 \mathrm{~Hz}), 4.74(\mathrm{t}, 1 \mathrm{H}, J=5.0 \mathrm{~Hz}), 6.01(\mathrm{dd}$, $1 \mathrm{H}, J=4.2$ and $1.0 \mathrm{~Hz}), 6.27(\mathrm{dd}, 1 \mathrm{H}, J=4.2$ and $2.6 \mathrm{~Hz}$ ), and $7.29(\mathrm{dd}, 1 \mathrm{H}, J=2.6$ and 1.0 $\mathrm{Hz}) ;{ }^{13} \mathrm{C}-\mathrm{NMR}\left(100 \mathrm{MHz}, \mathrm{CDCl}_{3}\right) \delta 18.6,22.8,25.5,25.7,26.3,34.1,36.4,38.7,46.5,97.3$, 
105.3, 110.3, 141.1, 145.8, 155.3, and 174.0; HRMS Calcd. for $\mathrm{C}_{16} \mathrm{H}_{21} \mathrm{NO}_{2}$ : 259.1572. Found: 259.1567.

\section{Acid Induced Dimerization of Hexahydroindolinone 20}

To a solution of $0.05 \mathrm{~g}(0.16 \mathrm{mmol})$ of hexahydroindolone 20 in $3 \mathrm{~mL}$ of $\mathrm{CH}_{2} \mathrm{Cl}_{2}$ was added trifluoroacetic acid $(0.04 \mathrm{~mL}, 0.5 \mathrm{mmol})$. The mixture was stirred at $\mathrm{rt}$ for $4 \mathrm{~h}$ and then the solvent was removed under reduced pressure. The crude product was purified by flash chromatography to give dimer 21 as a white crystalline solid in 54\% yield; mp 266-270 ${ }^{\circ} \mathrm{C}$; IR (KBr) 1686, 1398, 1208, and $1145 \mathrm{~cm}^{-1 ;}{ }_{1} \mathrm{H}-\mathrm{NMR}\left(400 \mathrm{MHz}, \mathrm{CDCl}_{3}\right) \delta 0.8(\mathrm{~s}, 6 \mathrm{H}), 1.20$ $1.53(\mathrm{~m}, 12 \mathrm{H}), 1.61(\mathrm{dd}, 2 \mathrm{H}, J=10.4$ and $4.0 \mathrm{~Hz}), 1.93(\mathrm{~m}, 4 \mathrm{H}), 2.01(\mathrm{~d}, 4 \mathrm{H}, J=16.0 \mathrm{~Hz}), 2.34$ (dt, $2 \mathrm{H}, 14.4$ and $8.0 \mathrm{~Hz}), 2.42(\mathrm{~d}, 2 \mathrm{H}, J=16.0 \mathrm{~Hz}), 2.58(\mathrm{dt}, 2 \mathrm{H}, J=14.4$ and 6.0), 2.74 (ddd, $2 \mathrm{H}, J=15.6,10.0$, and $5.6 \mathrm{~Hz}), 3.16(\mathrm{~m}, 2 \mathrm{H}), 5.95(\mathrm{~d}, 2 \mathrm{H} J=3.0 \mathrm{~Hz})$, and $6.02(\mathrm{~d}, 2 \mathrm{H}, J=3.0$ $\mathrm{Hz}) ;{ }^{13} \mathrm{C}-\mathrm{NMR}\left(100 \mathrm{MHz}, \mathrm{CDCl}_{3}\right) \delta 21.7,21.8,26.0,28.0,28.7,37.0,40.2,40.6,45.8,67.8$, 106.6, 109.3, 153.9, 155.2, and 177.2; HRMS Calcd. for $\mathrm{C}_{32} \mathrm{H}_{42} \mathrm{~N}_{2} \mathrm{O}_{4}$ : 518.3144. Found: 518.3133.

\section{Benzyl 1-(2-ethoxy-2-oxoethyl)-2-oxocyclohexanecarboxylate}

To a stirred solution of $0.21 \mathrm{~g}(5.2 \mathrm{mmol})$ of $\mathrm{NaH}(60 \%$ in mineral oil $)$ in $15 \mathrm{~mL}$ of THF at 0 ${ }^{\circ} \mathrm{C}$ was added a solution of $1 \mathrm{~g}(4.3 \mathrm{mmol})$ of benzyl 2-oxocyclohexanecarboxylate ${ }^{35}$ in $5 \mathrm{~mL}$ of THF. The reaction mixture was stirred for $30 \mathrm{~min}$ at $0{ }^{\circ} \mathrm{C}$ and then $0.8 \mathrm{~mL}(4.4 \mathrm{mmol})$ of HMPA was added, followed by the dropwise addition of $0.7 \mathrm{~mL}(6.5 \mathrm{mmol})$ of ethyl bromoacetate. The resulting solution was stirred for $4 \mathrm{~h}$ at $0{ }^{\circ} \mathrm{C}$ and then a saturated $\mathrm{NH}_{4} \mathrm{Cl}$ solution was added and the mixture was extracted with ether. The organic layer was dried over $\mathrm{MgSO}_{4}$, filtered and concentrated under reduced pressure. The crude mixture was subjected to flash silica gel chromatography to give $0.97 \mathrm{~g}(71 \%)$ of the titled compound as a colorless oil; IR (thin film) 2935, 1747, 1706, 1455, 1189 and $748 \mathrm{~cm}^{-1 ;}{ }_{1}^{1} \mathrm{H}-\mathrm{NMR}\left(\mathrm{CDCl}_{3}, 400 \mathrm{MHz}\right)$ $\delta 1.17(\mathrm{t}, 3 \mathrm{H}, J=7.2 \mathrm{~Hz}), 1.56-1.74(\mathrm{~m}, 4 \mathrm{H}), 1.93-1.99(\mathrm{~m}, 1 \mathrm{H}), 2.39-2.43(\mathrm{~m}, 2 \mathrm{H}), 2.61-2.69$ $(\mathrm{m}, 1 \mathrm{H}), 2.70(\mathrm{~s}, 2 \mathrm{H}), 4.04(\mathrm{qd}, 2 \mathrm{H}, J=7.0$ and $1.2 \mathrm{~Hz}), 5.12(\mathrm{~d}, 1 \mathrm{H}, J=12.2 \mathrm{~Hz}), 5.18(\mathrm{~d}, 1 \mathrm{H}$, $J=12.2 \mathrm{~Hz})$ and $7.27-7.32(\mathrm{~m}, 5 \mathrm{H}) ;{ }^{13} \mathrm{C}-\mathrm{NMR}\left(100 \mathrm{MHz}, \mathrm{CDCl}_{3}\right) \delta 14.1,22.0,27.0,36.7$, $39.8,40.5,58.9,60.6,67.3,128.3,128.4,128.6,135.4,170.8,171.3$ and 206.6.

\section{Benzyl 1-(3-(5-methylfuran-2-yl)propyl)-2-oxo-2,3,3a,4,5,6-hexahydro-1 H-indole-3a- carboxylate (24)}

To a solution of $0.32 \mathrm{~g}(1.0 \mathrm{mmol})$ of the above compound in $3 \mathrm{~mL}$ of xylene in a microwave tube was added $0.16 \mathrm{~g}(1.1 \mathrm{mmol})$ of 3-(5-methylfuran-2-yl)propan-1-amine (22). ${ }^{36}$ The tube was sealed and the mixture was heated under microwave irradiation for $20 \mathrm{~min}$ at $180{ }^{\circ} \mathrm{C}$. At the end of this time, the reaction mixture was subjected to flash silica gel chromatography to give $0.24 \mathrm{~g}(62 \%)$ of tetrahydroindolinone $\mathbf{2 4}$ as a pale yellow oil; IR (thin film) 1728, 1686, $1451,1399,1315,1277,1188$ and $779 \mathrm{~cm}^{-1 ; 1} \mathrm{H}-\mathrm{NMR}\left(\mathrm{CDCl}_{3}, 300 \mathrm{MHz}\right) \delta 1.43-1.62(\mathrm{~m}$, $2 \mathrm{H}), 1.70-1.93(\mathrm{~m}, 3 \mathrm{H}), 2.03-2.18(\mathrm{~m}, 1 \mathrm{H}), 2.22(\mathrm{~s}, 3 \mathrm{H}), 2.41(\mathrm{~d}, 1 \mathrm{H}, J=16.5 \mathrm{~Hz}), 2.45-2.57$ $(\mathrm{m}, 4 \mathrm{H}), 2.72(\mathrm{~d}, 1 \mathrm{H}, J=16.5 \mathrm{~Hz}), 3.21(\mathrm{ddd}, 1 \mathrm{H}, J=14.1,7.8$ and $5.7 \mathrm{~Hz}), 3.72(\mathrm{dt}, 1 \mathrm{H}, J=$ 13.8 and $7.5 \mathrm{~Hz}), 4.94(\mathrm{t}, 1 \mathrm{H}, J=3.6 \mathrm{~Hz}), 5.10(\mathrm{~s}, 2 \mathrm{H}), 5.82(\mathrm{~s}, 2 \mathrm{H})$ and $7.25-7.32(\mathrm{~m}$, 5H); ${ }^{13} \mathrm{C}-\mathrm{NMR}\left(75 \mathrm{MHz}, \mathrm{CDCl}_{3}\right) \delta$ 13.7, 19.6, 22.7, 25.3, 25.6, 31.3, 39.1, 42.0, 47.9, 67.2, 100.1, 105.8, 105.9, 128.1, 128.4, 128.6, 135.5, 139.5, 150.3, 153.2, 172.0 and 173.4; HRMS Calcd. for $\mathrm{C}_{24} \mathrm{H}_{27} \mathrm{NO}_{4}$ [M+H $\mathrm{H}^{+}$]: 394.2040. Found: 394.2033.

\section{1,2-Furanyl Fused Benzyl 7-Oxododecahydroazepino[1,2-i]indole-8a-carboxylate (25)}

To a solution of $0.1 \mathrm{~g}(0.25 \mathrm{mmol})$ of the above tetrahydro-indolone 24 in $5 \mathrm{~mL}$ of $\mathrm{CH}_{2} \mathrm{Cl}_{2}$ was added trifluoroacetic acid $(80 \mu \mathrm{L}, 1.0 \mathrm{mmol})$. The mixture was stirred at $\mathrm{rt}$ for $24 \mathrm{~h}$ and the solvent was then removed under reduced pressure. The crude residue was purified by flash chromatography on silica gel to give $0.09 \mathrm{~g}$ (95\%) of $\mathbf{2 5}$ as a clear oil; IR (thin film) 1730, 
1702, 1439, 1402, 1228, 1158 and $732 \mathrm{~cm}^{-1 ; 1} \mathrm{H}-\mathrm{NMR}\left(\mathrm{CDCl}_{3}, 400 \mathrm{MHz}\right) \delta 1.20-1.34(\mathrm{~m}$, 2H), 1.51-1.79 (m, 3H), 1.84-1.95 (m, 3H), 1.99-2.03 (m, 1H), $2.05(\mathrm{~s}, 3 \mathrm{H}), 2.14-2.23(\mathrm{~m}$, $2 \mathrm{H}), 2.55-2.58(\mathrm{~m}, 2 \mathrm{H}), 2.85-2.93(\mathrm{~m}, 2 \mathrm{H}), 4.27(\mathrm{dt}, 1 \mathrm{H}, J=14.2$ and $8.0 \mathrm{~Hz}), 5.08(\mathrm{~d}, 1 \mathrm{H}$, $J=12.4 \mathrm{~Hz}), 5.16(\mathrm{~d}, 1 \mathrm{H}, J=12.4 \mathrm{~Hz}), 5.58(\mathrm{~d}, 1 \mathrm{H}, J=0.8 \mathrm{~Hz})$ and $7.28-7.37(\mathrm{~m}, 5 \mathrm{H}) ;{ }^{13} \mathrm{C}-$ NMR $\left(100 \mathrm{MHz}, \mathrm{CDCl}_{3}\right) \delta 13.6,20.9,21.0,24.7,26.5,31.8,32.8,37.1,40.9,50.4,64.9,66.9$, 106.2, 123.7, 128.4, 128.5, 128.8, 135.5, 149.4, 151.9, 173.1 and 174.7; HRMS Calcd. for $\mathrm{C}_{24} \mathrm{H}_{27} \mathrm{NO}_{4}\left[\mathrm{M}+\mathrm{H}^{+}\right]:$394.2018. Found: 394.2013.

\section{2-(3-Azidopropyl)-5-ethyl-furan (26)}

To a solution of $0.45 \mathrm{~g}$ ( $2.9 \mathrm{mmol})$ of 1-hydroxy-non-5-yn-4-one 37 in $7 \mathrm{~mL}$ of $N, N$ dimethylacetamide in a sealed tube was added $29 \mathrm{mg}(0.15 \mathrm{mmol})$ of copper (I) iodide followed by $0.9 \mathrm{~mL}$ of triethylamine. The vessel was sealed and the mixture was heated at $100{ }^{\circ} \mathrm{C}$ for $24 \mathrm{~h}$. After cooling to $25^{\circ} \mathrm{C}$, water was added and the solution was extracted with ether and dried over sodium carbonate. The solution was concentrated under reduced pressure and the resulting furanyl alcohol was immediately used in the next step. ${ }^{38}$

The above alcohol was dissolved in $10 \mathrm{~mL}$ of $\mathrm{CH}_{2} \mathrm{Cl}_{2}$ at $0{ }^{\circ} \mathrm{C}$ and $0.3 \mathrm{~g}(2.7 \mathrm{mmol})$ of methanesulfonyl chloride was added followed by $0.6 \mathrm{~g}(6.2 \mathrm{mmol})$ of triethylamine. After warming to room temperature over $30 \mathrm{~min}$, the reaction mixture was quenched with water and extracted with $\mathrm{CH}_{2} \mathrm{Cl}_{2}$. The extracts were dried over $\mathrm{MgSO}_{4}$ and concentrated under reduced pressure. The crude mesylate was dried using a vacuum pump before being dissolved in $5 \mathrm{~mL}$ of DMF. Sodium azide $(0.3 \mathrm{~g}, 5 \mathrm{mmol})$ was added and the solution was stirred for $15 \mathrm{~h}$ at 50 ${ }^{\circ} \mathrm{C}$. To the mixture was added water and the solution was extracted with ether and the combined ether extracts were washed with brine, dried over $\mathrm{MgSO}_{4}$ and concentrated under reduced pressure. The crude product was purified by flash silica gel chromatography to give $0.35 \mathrm{~g}$ (78\%) of azide 26 as a pale yellow oil; IR (thin film) 2951, 2108, and $1315 \mathrm{~cm}^{-1 ; 1} \mathrm{H}-\mathrm{NMR}$ $\left(\mathrm{CDCl}_{3}, 400 \mathrm{MHz}\right) \delta 1.20(\mathrm{t}, 3 \mathrm{H}, J=7.6 \mathrm{~Hz}), 1.90(\mathrm{p}, 2 \mathrm{H}, J=6.8 \mathrm{~Hz}), 2.59$ (q, $\left.2 \mathrm{H}, J=7.2 \mathrm{~Hz}\right)$, $2.67(\mathrm{t}, 2 \mathrm{H}, J=7.2 \mathrm{~Hz}), 3.31(\mathrm{t}, 2 \mathrm{H}, J=6.8 \mathrm{~Hz}), 5.85(\mathrm{~d}, 1 \mathrm{H}, J=2.8 \mathrm{~Hz})$, and $5.89(\mathrm{~d}, 1 \mathrm{H}, J=$ $3.2 \mathrm{~Hz}) ;{ }^{13} \mathrm{C}-\mathrm{NMR}\left(\mathrm{CDCl}_{3}, 100 \mathrm{MHz}\right) \delta 12.4,21.5,25.3,27.7,50.9,104.4,106.1,152.7$, and 156.7 .

\section{1-[3-(5-Ethyl-furan-2-yl)propyl]-3a-methyl-1,3,3a,4,5,6-hexahydroindol-2-one (29)}

To a solution containing $0.35 \mathrm{~g}(2.0 \mathrm{mmol})$ of the above azide 26 in xylene $(5 \mathrm{~mL})$ in a microwave reaction tube was added tributylphosphine $(1.0 \mathrm{mmol})$. The mixture was stirred for $1 \mathrm{~h}$ at room temperature, the solvent was removed under reduced pressure and $5 \mathrm{~mL}$ of xylene was added followed by ketoacid $\mathbf{1 4}$. The reaction mixture was subjected to microwave irradiation at $180{ }^{\circ} \mathrm{C}$ for $10 \mathrm{~min}$. Removal of the solvent left a crude residue which was chromatographed on a silica gel column to give hexahydroindolinone $\mathbf{2 9}(80 \%)$ as a colorless oil; IR (thin film) 2935, 1721, 1681, 1455, and $1404 \mathrm{~cm}^{-1 ; 1} \mathrm{H}-\mathrm{NMR}\left(400 \mathrm{MHz}, \mathrm{CDCl}_{3}\right) \delta 1.18$ $(\mathrm{s}, 3 \mathrm{H}), 1.21(\mathrm{t}, 3 \mathrm{H}, J=7.6 \mathrm{~Hz}), 1.53(\mathrm{~m}, 1 \mathrm{H}), 1.70-1.90(\mathrm{~m}, 5 \mathrm{H}), 2.04-2.22(\mathrm{~m}, 2 \mathrm{H}), 2.25(\mathrm{~s}$, $3 \mathrm{H}), 2.59(\mathrm{~m}, 4 \mathrm{H}), 3.24(\mathrm{ddd}, 1 \mathrm{H}, J=14.0,8.4$ and $6.0 \mathrm{~Hz}), 3.67(\mathrm{ddd}, 1 \mathrm{H}, J=14.0,8.4$ and $7.2 \mathrm{~Hz}), 4.75(\mathrm{t}, 1 \mathrm{H}, J=3.6 \mathrm{~Hz})$, and $5.85(\mathrm{~d}, 1 \mathrm{H}, J=3.0 \mathrm{~Hz}) ;{ }^{13} \mathrm{C}-\mathrm{NMR}\left(100 \mathrm{MHz}, \mathrm{CDCl}_{3}\right)$ $\delta 12.4,18.5,21.5,22.8,25.5,25.7,26.3,34.0,36.3,38.8,46.5,97.3,104.4,105.7,145.8,153.3$, 156.4, and 173.9; HRMS Calcd. for $\mathrm{C}_{18} \mathrm{H}_{25} \mathrm{NO}_{2}$ : 287.1885. Found: 287.1879.

\section{2-Ethyl-9-methyl-9,9a-cyclohexyl-4,5,6,8,9,9a-hexahydro-3-oxa-6a-azacyclo-penta[e] azulen-7-one (30)}

To a solution of $0.1 \mathrm{~g}(0.3 \mathrm{mmol})$ of hexahydroindolone 29 in $3.5 \mathrm{~mL}$ of $\mathrm{CH}_{2} \mathrm{Cl}_{2}$ was added trifluoroacetic acid $(0.08 \mathrm{~mL}, 1.0 \mathrm{mmol})$. The mixture was stirred at $25^{\circ} \mathrm{C}$ for $4 \mathrm{~h}$ and the solvent was removed under reduced pressure. The crude product was purified by flash silica gel chromatography to give $\mathbf{3 0}$ as a colorless oil in 96\% yield; IR (thin film) 2936, 1774, 1689, and $1170 \mathrm{~cm}^{-1 ;}{ }^{1} \mathrm{H}-\mathrm{NMR}\left(400 \mathrm{MHz}, \mathrm{CDCl}_{3}\right) \delta 1.08(\mathrm{~s}, 3 \mathrm{H}), 1.20(\mathrm{t}, 3 \mathrm{H}, J=7.6 \mathrm{~Hz}), 1.41(\mathrm{~m}$, 
$1 \mathrm{H}), 1.57-1.75(\mathrm{~m}, 6 \mathrm{H}), 1.86(\mathrm{~m}, 1 \mathrm{H}), 2.00(\mathrm{~m}, 2 \mathrm{H}), 2.23(\mathrm{~d}, 1 \mathrm{H}, J=16.0 \mathrm{~Hz}), 2.38(\mathrm{~d}, 1 \mathrm{H}$, $J=16.4 \mathrm{~Hz}), 2.55(\mathrm{q}, 2 \mathrm{H}, \mathrm{J}=7.3 \mathrm{~Hz}), 2.69(\mathrm{~m}, 2 \mathrm{H}), 2.95(\mathrm{dt}, 1 \mathrm{H}, J=14.0$ and $6.8 \mathrm{~Hz}), 4.21(\mathrm{dt}$, $1 \mathrm{H}, J=14.6$ and $6.8 \mathrm{~Hz})$, and $5.88(\mathrm{~s}, 1 \mathrm{H}) ;{ }^{13} \mathrm{C}-\mathrm{NMR}\left(100 \mathrm{MHz}, \mathrm{CDCl}_{3}\right) \delta 12.2,21.4,21.5$, $22.0,23.9,24.8,25.8,33.7,35.3,37.4,40.9,43.8,67.4,105.5,122.5,150.0,155.0$, and 176.8; HRMS Calcd. for $\mathrm{C}_{18} \mathrm{H}_{25} \mathrm{NO}_{2}$ : 287.1885. Found: 287.1882.

\section{1-(2-(Furan-3-yl)ethyl)-3a-methyl-3a,4,5,6-tetrahydro-1 $H$-indol-2(3H)-one (31)}

To a $0{ }^{\circ} \mathrm{C}$ solution of $5 \mathrm{~g}(26 \mathrm{mmol})$ of commercially available furan-3-carbaldehyde in THF $(44 \mathrm{~mL})$ was added $2 \mathrm{~g}(52 \mathrm{mmol})$ of lithium aluminum hydride in portions. The reaction mixture was stirred at $0{ }^{\circ} \mathrm{C}$ for $30 \mathrm{~min}$. Following completion of the addition, the mixture was allowed to warm to room temperature and was quenched with a small amount of water and then $\mathrm{MgSO}_{4}$. The mixture was filtered and concentrated under reduced pressure. The resulting alcohol was dissolved in $87 \mathrm{~mL}$ of $\mathrm{CH}_{2} \mathrm{Cl}_{2}$ and cooled to $0{ }^{\circ} \mathrm{C}$ with stirring. After $5 \mathrm{~min}$, mesyl chloride $(3.0 \mathrm{~mL}, 39 \mathrm{mmol})$ and $\mathrm{Et}_{3} \mathrm{~N}(5.4 \mathrm{~mL}, 39 \mathrm{mmol})$ were added and the cold bath was removed. The reaction mixture was stirred at room temperature for $1 \mathrm{~h}$ and quenched with a saturated ammonium chloride solution. The organic layer was separated and the aqueous was extracted with $\mathrm{Et}_{2} \mathrm{O}$. The organic layers were combined, dried over $\mathrm{MgSO}_{4}$, filtered and concentrated under reduced pressure to give furan-3-ylmethyl methanesulfonate. To this compound was added $55 \mathrm{~mL}$ of DMF and $1 \mathrm{~g}(22 \mathrm{mmol})$ of sodium cyanide and the mixture was stirred vigorously overnight at room temperature. Water was added and the reaction mixture was extracted with $\mathrm{Et}_{2} \mathrm{O}$. The organic layers were washed with a saturated $\mathrm{NaCl}$ solution, dried over $\mathrm{MgSO}_{4}$, filtered and concentrated under reduced pressure. The resulting nitrile was dissolved in $26 \mathrm{~mL}$ of methanol and $2.5 \mathrm{~g}$ (10.5 mmol) of cobalt chloride-

hexahydrate was added with vigorous stirring. The mixture was cooled to $0{ }^{\circ} \mathrm{C}$ and $1.9 \mathrm{~g}(52$ mmol) of $\mathrm{NaBH}_{4}$ was then added. The solution was warmed to room temperature, stirred for $3.5 \mathrm{~h}$ and $3 \mathrm{~N} \mathrm{HCl}$ was added and the mixture was stirred for an additional $1.5 \mathrm{~h}$. The mixture was concentrated under reduced pressure and taken up in $\mathrm{NH}_{4} \mathrm{OH}$. The basified solution was extracted with EtOAc and dried over sodium sulfate. The solution was decanted and concentrated under reduced pressure to give $0.17 \mathrm{~g}$ of 2-(furan-3-yl)ethanamine $\mathrm{e}^{39}$ as a yellow oil which was immediately used in the next step; ${ }^{1} \mathrm{H}-\mathrm{NMR}\left(400 \mathrm{MHz}, \mathrm{CDCl}_{3}\right) \delta 1.60$ (brs, $2 \mathrm{H}), 2.53(\mathrm{t}, 2 \mathrm{H}, J=8.8 \mathrm{~Hz}), 2.86(\mathrm{t}, 2 \mathrm{H}, J=8.8 \mathrm{~Hz}), 6.26(\mathrm{~s}, 1 \mathrm{H}), 7.24(\mathrm{~d}, 1 \mathrm{H}, J=0.8 \mathrm{~Hz})$ and $7.34(\mathrm{~s}, 1 \mathrm{H}) ;{ }^{13} \mathrm{C}-\mathrm{NMR}\left(100 \mathrm{MHz}, \mathrm{CDCl}_{3}\right) \delta 29.1,42.4,110.9,122.5,139.6$ and 143.0.

To a solution containing $0.1 \mathrm{~g}(0.6 \mathrm{mmol})$ of keto acid $\mathbf{1 4} \mathrm{in} 2 \mathrm{~mL}$ of xylene in a microwave reaction tube was added $0.08 \mathrm{~g}(0.73 \mathrm{mmol})$ of the above 2-(furan-3-yl)ethanamine and the vessel was sealed. The mixture was subjected to microwave irradiation at $180^{\circ} \mathrm{C}$ for $20 \mathrm{~min}$. The solvent was then removed under reduced pressure and the crude residue was purified by flash silica gel chromatography to give $0.06 \mathrm{~g}$ (42\%) of $\mathbf{3 1}$ as a colorless oil; IR (neat) 1721, $1685,1407,1019,873$ and $786 \mathrm{~cm}^{-1 ; 1} \mathrm{H}-\mathrm{NMR}\left(400 \mathrm{MHz}, \mathrm{CDCl}_{3}\right) \delta 1.08(\mathrm{~s}, 3 \mathrm{H}), 1.46-1.56$ (m, 1H), 1.72-1.77 (m, 2H), 1.80 (q, 1H, $J=3.2 \mathrm{~Hz}$ ), 2.09 (ddd, $1 \mathrm{H}, J=17.6,9.2$ and $3.6 \mathrm{~Hz}$ ), $2.21(\mathrm{~s}, 2 \mathrm{H}), 2.25(\mathrm{dd}, 1 \mathrm{H}, J=8.8$ and $3.6 \mathrm{~Hz}), 2.66(\mathrm{t}, 2 \mathrm{H}, J=7.6 \mathrm{~Hz}), 3.33(\mathrm{dt}, 1 \mathrm{H}, J=13.6$ and $6.8 \mathrm{~Hz}), 3.87(\mathrm{dt}, 1 \mathrm{H}, J=14.0$ and $8.4 \mathrm{~Hz}), 4.78(\mathrm{t}, 1 \mathrm{H}, J=4.0 \mathrm{~Hz}), 6.31(\mathrm{~d}, 1 \mathrm{H}, J=0.4$ $\mathrm{Hz}), 7.24(\mathrm{dd}, 1 \mathrm{H}, J=1.2$ and $0.4 \mathrm{~Hz})$ and $7.33(\mathrm{t}, 1 \mathrm{H}, J=1.6 \mathrm{~Hz}) ;{ }^{13} \mathrm{C}-\mathrm{NMR}(100 \mathrm{MHz}$, $\left.\mathrm{CDCl}_{3}\right) \delta 18.5,22.2,22.8,26.1,34.0,36.3,39.2,46.4,97.4,111.1,121.5,139.7,143.1,145.6$ and 173.8; HRMS Calcd for $\mathrm{C}_{15} \mathrm{H}_{19} \mathrm{NO}_{2}\left[\mathrm{M}+\mathrm{H}^{+}\right]$: 246.1494. Found: 246.1481 .

\section{8-Methyl-8,8a-cyclohexyl-4,7,8,8a-tetrahydro-5H-oxa-5a-aza-as-indacen-6-one (32)}

To a solution of $0.03 \mathrm{~g}(0.12 \mathrm{mmol})$ of tetrahydroindolinone 31 in $2 \mathrm{~mL}$ of $\mathrm{CH}_{2} \mathrm{Cl}_{2}$ was added trifluoroacetic acid $(0.04 \mathrm{~mL}, 0.49 \mathrm{mmol})$ under argon. The reaction mixture was stirred at room temperature for $4 \mathrm{~h}$ and was then concentrated under reduced pressure. The resulting residue was purified by flash silica gel chromatography to give $0.04 \mathrm{~g}(98 \%)$ of $\mathbf{3 2}$ as a white crystalline solid, mp $120-122{ }^{\circ} \mathrm{C}$; IR (neat) $1688,1448,1410,1295,1170$ and $888 \mathrm{~cm}^{-1 ; 1} \mathrm{H}$ - 
NMR (400 MHz, CDCl $) \delta 0.61(\mathrm{~s}, 3 \mathrm{H}), 1.38(\mathrm{~m}, 1 \mathrm{H}), 1.52(\mathrm{dd}, 1 \mathrm{H}, J=13.4$ and $4.6 \mathrm{~Hz}), 1.59$ $1.74(\mathrm{~m}, 5 \mathrm{H}), 1.83(\mathrm{~d}, 1 \mathrm{H}, J=16 \mathrm{~Hz}), 2.13(\mathrm{~d}, 1 \mathrm{H}, J=12.8 \mathrm{~Hz}), 2.43(\mathrm{ddd}, 1 \mathrm{H}, J=15.6,4.8$ and $1.2 \mathrm{~Hz}), 2.54$ (ddd, $1 \mathrm{H}, J=15.6,11.4$ and $6.0 \mathrm{~Hz}), 2.73(\mathrm{~d}, 1 \mathrm{H}, J=16.0 \mathrm{~Hz}), 2.86$ (ddd, $1 \mathrm{H}$, $J=12.4,4.8$ and $1.2 \mathrm{~Hz}), 4.24$ (ddd, $1 \mathrm{H}, J=12.8,6.0$ and $1.2 \mathrm{~Hz}), 6.19(\mathrm{~d}, 1 \mathrm{H}, J=1.6 \mathrm{~Hz})$ and $7.26(\mathrm{~d}, 1 \mathrm{H}, J=2.0 \mathrm{~Hz}) ;{ }^{13} \mathrm{C}-\mathrm{NMR}\left(100 \mathrm{MHz}, \mathrm{CDCl}_{3}\right) \delta 22.0,22.1,22.8,25.9,33.7,34.7$, 35.5, 41.0, 42.2, 64.1, 110.1, 115.3, 141.6, 152.4 and 172.4; HRMS Calcd for $\mathrm{C}_{15} \mathrm{H}_{19} \mathrm{NO}_{2}[\mathrm{M}$ $+\mathrm{H}^{+}$]: 246.1494. Found: 246.1488.

\section{3a-Methyl-1-(2-thiophen-3-yl-ethyl)-1,3,3a,4,5,6-hexahydroindol-2-one (33)}

To a solution of $0.17 \mathrm{~g}(1.0 \mathrm{mmol})$ of keto acid $14 \mathrm{in} 3 \mathrm{~mL}$ of xylene in a micro-wave reaction tube was added $0.15 \mathrm{~g}$ (1.2 mmol) of 2-(thiophen-3-yl)ethanamine ${ }^{39}$ and the mixture was subjected to microwave irradiation at $175^{\circ} \mathrm{C}$ for $20 \mathrm{~min}$. Removal of the crude solvent left a crude residue which was purified by flash silica gel chromatography to give $0.14 \mathrm{~g}(55 \%)$ of 33 as a yellow oil; IR (neat) 3375, 1719, 1671, 1448, 1401, 1311,1159, and $779 \mathrm{~cm}^{-1 ; 1} \mathrm{H}-$ NMR $\left(600 \mathrm{MHz}, \mathrm{CDCl}_{3}\right) \delta 1.50(\mathrm{~s}, 3 \mathrm{H}), 1.47-1.53(\mathrm{~m}, 1 \mathrm{H}), 1.72-1.79(\mathrm{~m}, 3 \mathrm{H}), 2.08$ (ddd, $1 \mathrm{H}, J=12.0,6.0$ and $2.0 \mathrm{~Hz}), 2.20(\mathrm{~d}, 2 \mathrm{H}, J=2.4 \mathrm{~Hz}), 2.23(\mathrm{q}, 1 \mathrm{H}, J=2.8 \mathrm{~Hz}), 2.89(\mathrm{t}, 2 \mathrm{H}, J=$ $5.2 \mathrm{~Hz}$ ), $3.39(\mathrm{dt}, 1 \mathrm{H}, J=9.2$, and $4.4 \mathrm{~Hz}), 3.93(\mathrm{dt}, 1 \mathrm{H}, J=9.2$ and $5.2 \mathrm{~Hz}), 4.78(\mathrm{t}, 1 \mathrm{H}, J=2.8$ $\mathrm{Hz}), 6.96(\mathrm{~d}, 1 \mathrm{H}, J=3.2 \mathrm{~Hz}), 6.99(\mathrm{~d}, 1 \mathrm{H}, J=1.2 \mathrm{~Hz})$ and $7.23(\mathrm{dd}, 1 \mathrm{H}, J=3.2$ and 2.0 $\mathrm{Hz}) ;{ }^{13} \mathrm{C}-\mathrm{NMR}\left(150 \mathrm{MHz}, \mathrm{CDCl}_{3}\right) \delta 18.5,22.8,26.0,27.3,34.0,36.3,39.5,46.3,97.4,121.5$, 125.6, 128.3, 138.8, 145.5 and 173.8; HRMS Calcd for $\mathrm{C}_{15} \mathrm{H}_{19} \mathrm{NOS}\left[\mathrm{M}+\mathrm{H}^{+}\right]$: 262.1287. Found: 262.1254 .

\section{8-Methyl-8,8a-cyclohexyl-4,7,8,8a-tetrahydro-5H-mercapto-5a-aza-as-indacene-6-one (34)}

To a solution of $0.03 \mathrm{~g}(0.11 \mathrm{mmol})$ of tetrahydroindolinone $33 \mathrm{in} 1.1 \mathrm{~mL}$ of $\mathrm{CH}_{2} \mathrm{Cl}_{2}$ was added trifluoroacetic acid $(0.02 \mathrm{~mL}, 0.3 \mathrm{mmol})$ under argon. The reaction mixture was stirred at 25 ${ }^{\circ} \mathrm{C}$ for $4 \mathrm{~h}$, concentrated under reduced pressure and the resulting residue was purified by flash silica gel chromatography to give $0.02 \mathrm{~g}(73 \%)$ of 34 as a crystalline solid, mp $138-140{ }^{\circ} \mathrm{C}$; IR (neat) $3462,2919,1685,1445,1414$ and $861 \mathrm{~cm}^{-1 ; 1} \mathrm{H}-\mathrm{NMR}\left(400 \mathrm{MHz}, \mathrm{CDCl}_{3}\right) \delta 0.68$ (s, 3H), 1.45-1.55 (m, 1H), 1.57-1.66 (m, 1H), 1.69-1.79 (m, 5H), $1.91(\mathrm{~d}, 1 \mathrm{H}, J=16.0 \mathrm{~Hz})$, $2.18(\mathrm{dq}, 1 \mathrm{H}, J=12.8$ and $2.8 \mathrm{~Hz}), 2.63-2.77(\mathrm{~m}, 2 \mathrm{H}), 2.84(\mathrm{~d}, 1 \mathrm{H}, J=16.0 \mathrm{~Hz}), 2.94(\mathrm{tdd}, 1 \mathrm{H}$, $J=11.6,4.8$ and $1.6 \mathrm{~Hz}), 4.34(\mathrm{ddd}, 1 \mathrm{H}, J=13.2,6.0$ and $1.6 \mathrm{~Hz}), 6.83(\mathrm{~d}, 1 \mathrm{H}, J=4.8 \mathrm{~Hz})$ and $7.15(\mathrm{~d}, 1 \mathrm{H}, J=4.8 \mathrm{~Hz}) ;{ }^{13} \mathrm{C}-\mathrm{NMR}\left(100 \mathrm{MHz}, \mathrm{CDCl}_{3}\right) \delta 21.6,22.2,26.1,26.2,32.8,34.4$, 37.0, 41.3, 41.9, 65.7, 123.0, 127.0, 134.1, 136.3 and 171.9; Anal. Calcd. for $\mathrm{C}_{15} \mathrm{H}_{19} \mathrm{NOS}: \mathrm{C}$, 68.93; H, 7.33; N, 5.36. Found: C, 68.79; H, 7.34; N, 5.39.

\section{3a-Methyl-1-(2-thiophen-2-ylethyl)-1,3,3a,4,5,6-hexahydroindol-2-one (35)}

To a solution containing $0.11 \mathrm{~g}(0.68 \mathrm{mmol})$ of keto acid $14 \mathrm{in} 1 \mathrm{~mL}$ of xylene in a microwave reaction tube was added $0.1 \mathrm{~mL}(0.86 \mathrm{mmol})$ of 2-thiophen-2-yl-ethanamine ${ }^{39}$ and the vessel was subjected to microwave irradiation at $180^{\circ} \mathrm{C}$ for $20 \mathrm{~min}$. The crude residue obtained upon removal of the solvent was purified by flash silica gel chromatography to give $0.14 \mathrm{~g} \mathrm{(79 \% )}$ of $\mathbf{3 5}$ as a pale yellow oil; IR (neat) $1676,1452,1404,1317,1171$ and $695 \mathrm{~cm}^{-1 ; 1} \mathrm{H}-\mathrm{NMR}$ $\left(600 \mathrm{MHz}, \mathrm{CDCl}_{3}\right) \delta 1.10(\mathrm{~s}, 3 \mathrm{H}), 1.51(\mathrm{~m}, 1 \mathrm{H}), 1.75(\mathrm{~m}, 2 \mathrm{H}), 1.79(\mathrm{t}, 1 \mathrm{H}, J=3.2 \mathrm{~Hz}), 2.08(\mathrm{qd}$, $1 \mathrm{H}, J=9.0$ and $3.6 \mathrm{~Hz}), 2.22(\mathrm{~m}, 3 \mathrm{H}), 3.04(\mathrm{~m}, 2 \mathrm{H}), 3.44(\mathrm{~m}, 1 \mathrm{H}), 3.92(\mathrm{~m}, 1 \mathrm{H}), 4.78(\mathrm{t}, 1 \mathrm{H}$, $J=4.0 \mathrm{~Hz}), 6.84(\mathrm{~m}, 1 \mathrm{H}), 6.90(\mathrm{dd}, 1 \mathrm{H}, J=4.8$ and $3.6 \mathrm{~Hz})$ and $7.11(\mathrm{dd}, 1 \mathrm{H}, \mathrm{J}=5.0$ and 1.4 $\mathrm{Hz}) ;{ }^{13} \mathrm{C}-\mathrm{NMR}\left(150 \mathrm{MHz}, \mathrm{CDCl}_{3}\right) \delta$ 18.5, 22.8, 26.1, 27.1, 34.0, 36.3, 40.6, 46.4, 97.3, 123.9, 125.4, 127.0, 140.8, 145.5 and 173.8; HRMS Calcd for $\mathrm{C}_{15} \mathrm{H}_{19} \mathrm{NOS}\left[\mathrm{M}+\mathrm{H}^{+}\right]$: 262.1287.

Found: 262.1282 .

\section{8-Methyl-8,8a-cyclohexyl-4,7,8,8a-tetrahydro-5H-mercapto-5a-aza-as-indacene-6-one (36)}

A mixture containing tetrahydroindolinone 35 in $5 \mathrm{~mL}$ of polyphosphoric acid was stirred at $90{ }^{\circ} \mathrm{C}$ for $12 \mathrm{~h}$. The reaction mixture was poured into ice water and extracted with $\mathrm{CHCl}_{3}$. The 
organic layer was washed with $\mathrm{H}_{2} \mathrm{O}$, dried over $\mathrm{MgSO}_{4}$, filtered and concentrated under reduced pressure. The crude product was purified by silica gel column chromatography to give $0.01 \mathrm{~g}(33 \%)$ of $\mathbf{3 6}$ as a yellow solid, $\mathrm{mp} 102-104^{\circ} \mathrm{C}$; IR (neat) 1683, 1450, 1416, 1325, 1239 , 1032 and $727 \mathrm{~cm}^{-1 ;}{ }_{1} \mathrm{H}-\mathrm{NMR}\left(400 \mathrm{MHz}, \mathrm{CDCl}_{3}\right) \delta 0.66(\mathrm{~s}, 3 \mathrm{H}), 1.65(\mathrm{~m}, 7 \mathrm{H}), 1.91(\mathrm{~d}, 1 \mathrm{H}$, $J=16 \mathrm{~Hz}$ ), $2.16(\mathrm{~m}, 1 \mathrm{H}), 2.80(\mathrm{~s}, 1 \mathrm{H}), 2.86(\mathrm{~m}, 2 \mathrm{H}), 3.02(\mathrm{~m}, 1 \mathrm{H}), 4.39$ (ddd, $1 \mathrm{H}, J=13.2,4.8$ and $2.8 \mathrm{~Hz}), 7.06(\mathrm{~d}, 1 \mathrm{H}, J=5.6 \mathrm{~Hz})$ and $7.15(\mathrm{~d}, 1 \mathrm{H}, J=4.8 \mathrm{~Hz}) ;{ }^{13} \mathrm{C}-\mathrm{NMR}(100 \mathrm{MHz}$, $\left.\mathrm{CDCl}_{3}\right) \delta 21.8,25.2,26.5,33.3,34.4,36.8,40.6,42.2,65.2,78.9,122.9,125.1,133.6,137.3$ and 171.9; HRMSCalcd for $\mathrm{C}_{15} \mathrm{H}_{19} \mathrm{NOS}\left[\mathrm{M}+\mathrm{H}^{+}\right]$: 262.1287. Found: 262.1281 .

\section{8-Methyl-8,8a-cyclohexyl-3,4,5,7,8,8a-hexahydro-3,5a-diaza-as-indacen-6-one (38)}

To a solution of $0.02 \mathrm{~g}(0.13 \mathrm{mmol})$ of keto acid $14 \mathrm{in} 2 \mathrm{~mL}$ of xylene in a microwave reaction tube was added $0.02 \mathrm{~g}(0.14 \mathrm{mmol})$ of 2-(1H-pyrrol-2-yl)ethanamine ${ }^{40}$ and the mixture was subjected to microwave irradiation at $70{ }^{\circ} \mathrm{C}$ for $30 \mathrm{~min}$. The solution was concentrated under reduced pressure and the resulting residue was purified by flash silica gel chromatography to give $0.02 \mathrm{~g}(70 \%)$ of 38 as a clear oil; IR (neat) $3315,2925,1762,1653,1451,1232,1099$ and $917 \mathrm{~cm}^{-1 ; 1} \mathrm{H}-\mathrm{NMR}\left(400 \mathrm{MHz}, \mathrm{CDCl}_{3}\right) \delta 0.67(\mathrm{~s}, 3 \mathrm{H}), 1.46-1.78(\mathrm{~m}, 7 \mathrm{H}), 1.88(\mathrm{~d}, 1 \mathrm{H}, J=16.0$ $\mathrm{Hz}), 2.10-2.14(\mathrm{~m}, 1 \mathrm{H}), 2.61(\mathrm{dd}, 1 \mathrm{H}, J=14.8$ and $4.4 \mathrm{~Hz}$ ), 2.73 (ddd, $1 \mathrm{H}, J=14.8,11.6$ and $6.0 \mathrm{~Hz}), 2.80(\mathrm{~d}, 1 \mathrm{H}, J=16.0 \mathrm{~Hz}), 3.01(\mathrm{tdd}, 1 \mathrm{H}, J=12.4,4.8$ and $1.6 \mathrm{~Hz}), 4.34(\mathrm{ddd}, 1 \mathrm{H}, J=$ $13.2,6.0$ and $1.2 \mathrm{~Hz}), 6.14(\mathrm{t}, 1 \mathrm{H}, J=2.8 \mathrm{~Hz}), 6.67(\mathrm{t}, 1 \mathrm{H}, J=2.8 \mathrm{~Hz})$ and $8.21(\mathrm{~s}, 1 \mathrm{H}) ;{ }^{13} \mathrm{C}-$ NMR $\left(100 \mathrm{MHz}, \mathrm{CDCl}_{3}\right) \delta 22.0,22.1,22.9,26.7,33.5,34.1,37.2,40.7,42.2,64.4,105.8$, 116.5, 119.7, 123.9 and 172.6; Anal. Calcd. for $\mathrm{C}_{15} \mathrm{H}_{20} \mathrm{~N}_{2} \mathrm{O}$ : C, 73.74; H, 8.25; N, 11.47 . Found: C, 73.56; H, 8.28; N, 11.25.

\section{1 -Methyl-1,11b-cyclohexyl-1,2,5,6,11,11b-hexahydroindolizino[8,7-b]indol-3-one (40)}

To a solution of $0.17 \mathrm{~g}(1.0 \mathrm{mmol})$ of keto acid $14 \mathrm{in} 1 \mathrm{~mL}$ of xylene in a microwave reaction tube was added $0.19 \mathrm{~g}(1.2 \mathrm{mmol})$ of 2-(1H-indol-3-yl)ethan amine $(\mathbf{3 9})$ and trifluoroacetic acid $(0.08 \mathrm{~mL}, 1.0 \mathrm{mmol})$ and the mixture was subjected to microwave irradiation at $180{ }^{\circ} \mathrm{C}$ for $20 \mathrm{~min}$. The solution was concentrated under reduced pressure and the residue was purified by flash silica gel chromatography to give $0.25 \mathrm{~g}(85 \%)$ of $\mathbf{4 0}$ as a crystalline solid: $\mathrm{mp} 268-$ $269^{\circ} \mathrm{C}$; IR (neat) $3271,1662,1421,1290,1021$ and $746 \mathrm{~cm}^{-1 ;}{ }_{1} \mathrm{H}-\mathrm{NMR}\left(600 \mathrm{MHz}, \mathrm{CDCl}_{3}\right)$ $\delta 0.89(\mathrm{~s}, 3 \mathrm{H}), 1.97(\mathrm{~m}, 7 \mathrm{H}), 2.21(\mathrm{dd}, 1 \mathrm{H}, J=13.2$ and $3.6 \mathrm{~Hz}), 2.45(\mathrm{~d}, 1 \mathrm{H}, J=13.2 \mathrm{~Hz})$, $2.88(\mathrm{~m}, 1 \mathrm{H}), 3.08(\mathrm{dd}, 1 \mathrm{H}, \mathrm{J}=15.6$ and $4.2 \mathrm{~Hz}), 3.12(\mathrm{~d}, 1 \mathrm{H}, \mathrm{J}=16.2 \mathrm{~Hz}), 3.25(\mathrm{dd}, 1 \mathrm{H}, J=$ 12 and $4.2 \mathrm{~Hz}), 4.50(\mathrm{dd}, 1 \mathrm{H}, J=12.6$ and $6.0 \mathrm{~Hz}), 7.28(\mathrm{t}, 1 \mathrm{H}, J=7.8 \mathrm{~Hz}), 7.37(\mathrm{t}, 1 \mathrm{H}, J=$ $7.8 \mathrm{~Hz}), 7.71(\mathrm{~m}, 2 \mathrm{H})$ and $10.93(\mathrm{~s}, 1 \mathrm{H}) ;{ }^{13} \mathrm{C}-\mathrm{NMR}\left(150 \mathrm{MHz}, \mathrm{CDCl}_{3}\right) \delta 21.0,21.1,21.2,25.9$, $32.3,33.9,35.5,41.5,63.1,96.8,106.7,111.5,117.8,118.6,121.0,125.9,135.5,136.3$ and 170.4; Anal. Calcd. for $\mathrm{C}_{19} \mathrm{H}_{22} \mathrm{~N}_{2} \mathrm{O}$ : C, 77.52; H, 7.53; N, 9.52. Found: C, 77.13; H, 7.52; N, 9.47 .

\section{1-Methyl-1,10c-cyclohexyl-1,2,4,5,6,10c-hexahydro-3a,6-diazacyclopenta[c]-fluoren-3-one} (42)

To a solution of $0.05 \mathrm{~g}(0.3 \mathrm{mmol})$ of keto acid $14 \mathrm{in} 2 \mathrm{~mL}$ of xylene in a microwave reaction tube was added $0.058 \mathrm{~g}(0.36 \mathrm{mmol})$ of 2-( $1 H$-indol-2-yl)ethanamine $(\mathbf{4 1})^{41}$ and the vessel was subjected to microwave irradiation at $180^{\circ} \mathrm{C}$ for $20 \mathrm{~min}$. The solution was concentrated under reduced pressure and the residue was purified by flash silica gel chromatography to give $0.05 \mathrm{~g}(90 \%)$ of 42 as a yellow oil; IR (neat) $3262,2921,1662,1450,1321$ and $746 \mathrm{~cm}^{-1 ; 1} \mathrm{H}$ NMR (300 MHz, $\left.\mathrm{CDCl}_{3}\right) \delta 0.79(\mathrm{~s}, 3 \mathrm{H}), 1.55-1.97(\mathrm{~m}, 4 \mathrm{H}), 2.02(\mathrm{~d}, 1 \mathrm{H}, J=16.5 \mathrm{~Hz}), 2.14$ $2.33(\mathrm{~m}, 4 \mathrm{H}), 2.72(\mathrm{dd}, 1 \mathrm{H}, J=16.0$ and $4.8 \mathrm{~Hz}), 2.86(\mathrm{~d}, 1 \mathrm{H}, J=16.5 \mathrm{~Hz}), 2.91-3.00(\mathrm{~m}, 1 \mathrm{H})$, $3.08(\mathrm{td}, 1 \mathrm{H}, J=12.3$ and $4.8 \mathrm{~Hz}), 4.46(\mathrm{dd}, 1 \mathrm{H}, J=12.9$ and $5.7 \mathrm{~Hz}), 7.07-7.17(\mathrm{~m}, 2 \mathrm{H}), 7.32$ $(\mathrm{d}, 1 \mathrm{H}, J=7.8 \mathrm{~Hz}), 7.78(\mathrm{~d}, 1 \mathrm{H}, J=7.8 \mathrm{~Hz})$ and $8.25(\mathrm{~s}, 1 \mathrm{H}) ;{ }^{13} \mathrm{C}-\mathrm{NMR}\left(75 \mathrm{MHz}, \mathrm{CDCl}_{3}\right) \delta$ 20.5, 21.0, 23.8, 27.2, 32.8, 33.8, 36.8, 40.0, 43.6, 66.7, 111.2, 114.1, 119.7, 121.0,121.5,125.6, 132.3, 136.0 and 172.5; HRMS Calcd for $\mathrm{C}_{19} \mathrm{H}_{22} \mathrm{~N}_{2} \mathrm{O}\left[\mathrm{M}+\mathrm{H}^{+}\right]$: 295.1810. Found: 295.1808 . 
In addition, varying amounts of the oxidized 1-methyl-1, 10c-cyclohexyl-1,2,6,10ctetrahydro-3a,6-diazacyclopenta[c]-fluoren-3-one derived from $\mathbf{4 2}$ was also isolated as a pale yellow oil; IR (neat) 3278, 2925, 1685, 1629, 1450, 1414, 1368 and $753 \mathrm{~cm}^{-1 ; 1} \mathrm{H}-\mathrm{NMR}(600$ $\left.\mathrm{MHz}, \mathrm{CDCl}_{3}\right) \delta 1.21(\mathrm{~s}, 3 \mathrm{H}), 1.50-1.62(\mathrm{~m}, 4 \mathrm{H}), 1.93-1.99(\mathrm{~m}, 2 \mathrm{H}), 2.06(\mathrm{~d}, 1 \mathrm{H}, J=16.8 \mathrm{~Hz})$, $2.33-2.39(\mathrm{~m}, 2 \mathrm{H}), 2.92(\mathrm{~d}, 1 \mathrm{H}, J=16.8 \mathrm{~Hz}), 5.86(\mathrm{~d}, 1 \mathrm{H}, J=7.2 \mathrm{~Hz}), 6.99(\mathrm{~d}, 1 \mathrm{H}, J=7.2$ $\mathrm{Hz}), 7.12(\mathrm{~m}, 2 \mathrm{H}), 7.31-7.32(\mathrm{~m}, 1 \mathrm{H}), 7.80-7.81(\mathrm{~m}, 1 \mathrm{H})$ and $8.16(\mathrm{~s}, 1 \mathrm{H}) ;{ }^{13} \mathrm{C}-\mathrm{NMR}(100$ $\left.\mathrm{MHz}, \mathrm{CDCl}_{3}\right) \delta 22.0,22.3,26.9,34.2,40.2,42.1,42.8,70.1,100.7,102.0,111.5,120.6,120.8$, 121.6, 122.0, 125.7, 131.7, 136.5 and 173.0; HRMS Calcd. for $\mathrm{C}_{19} \mathrm{H}_{20} \mathrm{~N}_{2} \mathrm{O}\left[\mathrm{M}+\mathrm{H}^{+}\right]$: 293.1654 . Found: 293.1649 .

\section{2-[(2-Ethylsulfanylacetyl)-(2-furan-2-yl-ethyl)amino]cyclohex-1-ene-carboxylic Acid Ethyl Ester (44)}

To a solution of $7.7 \mathrm{~g}(68 \mathrm{mmol})$ of 2-furan-2-yl-ethan-1-ol ${ }^{33}$ in $140 \mathrm{~mL}$ of $\mathrm{CH}_{2} \mathrm{Cl}_{2}$ at $0{ }^{\circ} \mathrm{C}$ was added $8.3 \mathrm{~g}(72 \mathrm{mmol})$ of methanesulfonylchloride followed by the slow addition of 10.4 $\mathrm{g}(100 \mathrm{mmol})$ of triethylamine. The solution was warmed to room temperature over $30 \mathrm{~min}$, quenched with water and extracted with $\mathrm{CH}_{2} \mathrm{Cl}_{2}$. The organic extracts were dried over $\mathrm{MgSO}_{4}$, filtered and concentrated under reduced pressure. The crude product was taken up in $140 \mathrm{~mL}$ of DMF and $8.9 \mathrm{~g}(130 \mathrm{mmol})$ of sodium azide was added. The reaction was stirred at $50{ }^{\circ} \mathrm{C}$ for $15 \mathrm{~h}$. After cooling to $25^{\circ} \mathrm{C}, 350 \mathrm{~mL}$ of water was added and the solution was extracted with ether. The ether extracts were washed with brine, dried over $\mathrm{MgSO}_{4}$, concentrated under reduced pressure and subjected to flash silica gel chromatography to give $8.3 \mathrm{~g}(88 \%)$ of 2-(2-azidoethyl)furan as a pale yellow oil which was used in the next step without further purification; ${ }^{1} \mathrm{H}-\mathrm{NMR}\left(400 \mathrm{MHz}, \mathrm{CDCl}_{3}\right) \delta 2.90(\mathrm{t}, 2 \mathrm{H}, J=7.6 \mathrm{~Hz}), 3.55(\mathrm{t}$, $2 \mathrm{H}, J=7.6 \mathrm{~Hz}), 6.15(\mathrm{~m}, 1 \mathrm{H}), 6.30(\mathrm{~m}, 1 \mathrm{H})$, and $7.30(\mathrm{~m}, 1 \mathrm{H}) ;{ }^{13} \mathrm{C}-\mathrm{NMR}(150 \mathrm{MHz}$, $\left.\mathrm{CDCl}_{3}\right) \delta 28.2,49.9,107.0,110.6,141.8$, and 152.0.

To a solution of $0.3 \mathrm{~g}$ of the above azide $(2.5 \mathrm{mmol})$ in $12 \mathrm{~mL}$ of toluene was added tributylphosphine $(2.5 \mathrm{mmol})$. The reaction mixture was stirred for $1 \mathrm{~h}$ at room temperature and 2-oxo-cyclohexanecarboxylic acid ethyl ester $(2.5 \mathrm{mmol})$ was added and the vessel was sealed with a septum. The reaction mixture was subjected to microwave irradiation at $150{ }^{\circ} \mathrm{C}$ for $30 \mathrm{~min}$. After cooling to $0{ }^{\circ} \mathrm{C}$, powdered $4 \AA$ molecular sieves $(2.5 \mathrm{~g})$ was added followed by a solution of (ethylsulfanyl)acetyl chloride (prepared from $0.37 \mathrm{~g}, 3.0 \mathrm{mmol}$ of (ethylsulfanyl)-acetic acid). After warming to room temperature overnight, the solution was filtered and concentrated under reduced pressure. The residue was subjected to flash silica gel chromatography to give $0.4 \mathrm{~g}(44 \%)$ of $\mathbf{4 4}$ as a colorless oil; ${ }^{1} \mathrm{H}-\mathrm{NMR}\left(400 \mathrm{MHz}, \mathrm{CDCl}_{3}\right) \delta$ $1.26(\mathrm{t}, 6 \mathrm{H}, J=7.2 \mathrm{~Hz}), 1.66(\mathrm{~m}, 4 \mathrm{H}), 2.15(\mathrm{~m}, 1 \mathrm{H}), 2.21(\mathrm{~m}, 1 \mathrm{H}), 2.38(\mathrm{~m}, 2 \mathrm{H}), 2.68(\mathrm{~m}, 2 \mathrm{H})$, $2.88(\mathrm{~m}, 1 \mathrm{H}), 2.99(\mathrm{~m}, 1 \mathrm{H}), 3.19(\mathrm{~m}, 1 \mathrm{H}), 3.32(\mathrm{~m}, 1 \mathrm{H}), 3.57(\mathrm{~m}, 1 \mathrm{H}), 3.75(\mathrm{~m}, 1 \mathrm{H}), 4.14(\mathrm{qd}$, $2 \mathrm{H}, J=7.2$ and $2.4 \mathrm{~Hz}), 6.04(\mathrm{~d}, 1 \mathrm{H}, J=3.2 \mathrm{~Hz}), 6.27(\mathrm{dd}, 1 \mathrm{H}, J=2.8$ and $2.4 \mathrm{~Hz}), 7.30(\mathrm{~d}$, $1 \mathrm{H}, J=2.0 \mathrm{~Hz}) ;{ }^{13} \mathrm{C}-\mathrm{NMR}\left(100 \mathrm{MHz}, \mathrm{CDCl}_{3}\right) \delta 14.3,14.5,21.6,22.4,26.6,26.7,26.9,30.4$, 33.3, 47.0, 61.3, 106.4, 110.5, 129.5, 141.3, 145.1, 153.3, 167.2, and 169.1; HRMS Calcd. for $\mathrm{C}_{19} \mathrm{H}_{27} \mathrm{NO}_{4} \mathrm{~S}\left[\mathrm{M}+\mathrm{H}^{+}\right]: 366.1739$. Found: 366.1741.

\section{2-[(2-Ethanesulfinylacetyl)-(2-furan-2-ylethyl)amino]cyclohex-1-ene-carboxylic Acid Ethyl Ester (46)}

To a solution of $0.4 \mathrm{~g}(1.1 \mathrm{mmol})$ of the above sulfide $44 \mathrm{in} 5 \mathrm{~mL}$ of $20 \%$ aqueous methanol was added $0.5 \mathrm{~g}(2.2 \mathrm{mmol})$ of sodium periodate. After stirring for $15 \mathrm{~h}$ at room temperature, water was added and the solution was extracted with chloroform. The chloroform layer was dried over $\mathrm{MgSO}_{4}$, filtered and concentrated under reduced pressure. The crude product was purified using flash silica gel chromatography to give $0.39 \mathrm{~g}(95 \%)$ of sulfoxide $\mathbf{4 6}$ as a colorless oil; ${ }^{1} \mathrm{H}-\mathrm{NMR}\left(400 \mathrm{MHz}, \mathrm{CDCl}_{3}\right) \delta 1.28(\mathrm{dt}, 3 \mathrm{H}, J=7.6$ and $7.2 \mathrm{~Hz}), 1.39(\mathrm{t}, 3 \mathrm{H}, J=7.6 \mathrm{~Hz})$, $1.67(\mathrm{~m}, 4 \mathrm{H}), 2.14(\mathrm{~m}, 2 \mathrm{H}), 2.42(\mathrm{~m}, 2 \mathrm{H}), 2.83(\mathrm{~m}, 2 \mathrm{H}), 2.96(\mathrm{~m}, 1 \mathrm{H}), 3.15(\mathrm{M}, 1 \mathrm{H}), 3.59$ $3.90(\mathrm{~m}, 4 \mathrm{H}), 4.16(\mathrm{dq}, 2 \mathrm{H}, J=11.6$ and $7.2 \mathrm{~Hz}), 6.04(\mathrm{dd}, 1 \mathrm{H}, J=4.0$ and $3.6 \mathrm{~Hz}), 6.28(\mathrm{dd}$, 
$1 \mathrm{H}, J=2.4 \mathrm{~Hz})$, and $7.30(\mathrm{dd}, 1 \mathrm{H}, J=0.8$ and $0.8 \mathrm{~Hz}) ;{ }^{13} \mathrm{C}-\mathrm{NMR}\left(100 \mathrm{MHz}, \mathrm{CDCl}_{3}\right) \delta 6.59$, 6.87, 14.3, 21.5, 22.3, 26.6, 26.7, 26.8, 26.9, 30.5, 30.7, 46.5, 46.8, 47.1, 54.9, 56.5, 61.4, 61.5, 106.6, 110.6, 130.7, 141.5, 144.1, 152.7, 164.5, and 166.8; HRMS Calcd. for $\mathrm{C}_{19} \mathrm{H}_{27} \mathrm{NO}_{5} \mathrm{~S}[\mathrm{M}$ $+\mathrm{H}^{+}$]: 382.1688. Found: 382.1685 .

\section{1,2-Furanyl Fused Ethyl 6-Oxodecahydro-1 $H$-pyrido[1,2-I] indole-7a-carboxylate (48)}

To a solution of $0.24 \mathrm{~g}(0.6 \mathrm{mmol})$ of sulfoxide 46 in $6 \mathrm{~mL}$ of $\mathrm{CH}_{2} \mathrm{Cl}_{2}$ at $0{ }^{\circ} \mathrm{C}$ was added 0.14 $\mathrm{g}(0.69 \mathrm{mmol})$ of trifluoroacetic anhydride. After stirring for $10 \mathrm{~min}$ at $0{ }^{\circ} \mathrm{C}, 0.15 \mathrm{~mL}$ of trifluoroacetic acid was added and the mixture was allowed to warm to room temperature over $2 \mathrm{~h}$. The reaction was concentrated under reduced pressure and the residue was subjected to flash silica gel chromatography to give $0.17 \mathrm{~g}(76 \%)$ of $\mathbf{4 8}$ as a colorless oil which consisted of a single diastereomer; ${ }^{1} \mathrm{H}-\mathrm{NMR}\left(400 \mathrm{MHz}, \mathrm{CDCl}_{3}\right) \delta 0.95(\mathrm{t}, 3 \mathrm{H}, J=7.2 \mathrm{~Hz}), 1.30(\mathrm{t}, 3 \mathrm{H}$, $J=7.6 \mathrm{~Hz}), 1.44(\mathrm{~m}, 1 \mathrm{H}), 1.53(\mathrm{~m}, 1 \mathrm{H}), 1.66(\mathrm{~m}, 1 \mathrm{H}), 1.74(\mathrm{~m}, 1 \mathrm{H}), 1.96(\mathrm{~d}, 1 \mathrm{H}, J=14.0 \mathrm{~Hz})$, $2.17(\mathrm{~d}, 1 \mathrm{H}, J=15.6 \mathrm{~Hz}), 2.23(\mathrm{~d}, 1 \mathrm{H}, J=12.8 \mathrm{~Hz}), 2.36(\mathrm{~m}, 1 \mathrm{H}), 2.70(\mathrm{~m}, 4 \mathrm{H}), 3.06(\mathrm{~m}, 1 \mathrm{H})$, $3.65(\mathrm{~s}, 1 \mathrm{H}), 3.81(\mathrm{q}, 2 \mathrm{H}, J=6.8 \mathrm{~Hz}), 4.50(\mathrm{ddd}, 1 \mathrm{H}, J=12.8,6.0$, and $0.8 \mathrm{~Hz}), 6.38(\mathrm{~d}, 1 \mathrm{H}$, $J=0.8 \mathrm{~Hz})$, and $7.24(\mathrm{~d}, 1 \mathrm{H}, J=0.8 \mathrm{~Hz}) ;{ }^{13} \mathrm{C}-\mathrm{NMR}\left(100 \mathrm{MHz}, \mathrm{CDCl}_{3}\right) \delta 13.8,15.4,21.2$, 21.5, 23.1, 26.1, 28.9, 34.7, 37.6, 51.8, 57.8, 60.8,61.1, 108.4, 119.2, 141.4, 148.0,170.1 and 171.3; HRMS Calcd. for $\mathrm{C}_{19} \mathrm{H}_{25} \mathrm{NO}_{4} \mathrm{~S}$ [M+H']: 364.1582. Found: 364.1580 .

\section{2-[[3-(5-Ethyl-furan-2-yl)propyl]-(2-ethylsulfanylacetyl)amino]cyclohex-1-enecarboxylic Acid Ethyl Ester (45)}

To a solution of $0.37 \mathrm{~g}$ of 2-(3-azido-propyl)-5-ethyl-furan (26) (2.4 mmol) in $12 \mathrm{~mL}$ of toluene was added tributylphosphine $(2.4 \mathrm{mmol})$. The reaction mixture was stirred for $1 \mathrm{~h}$ at room temperature and then 2-oxo-cyclohexane-carboxylic acid ethyl ester $(0.4 \mathrm{~g}, 2.5 \mathrm{mmol})$ was added and the vessel was sealed with a septum. The reaction mixture was subjected to microwave irradiation at $150{ }^{\circ} \mathrm{C}$ for $30 \mathrm{~min}$. After cooling to $0{ }^{\circ} \mathrm{C}$, powdered $4 \AA$ molecular sieves $(2.5 \mathrm{~g}$ ) was added followed by a solution of (ethylsulfanyl)acetyl chloride (prepared from $0.37 \mathrm{~g}, 3.0 \mathrm{mmol}$ of (ethylsulfanyl)-acetic acid). After warming to room temperature overnight, the solution was filtered and concentrated under reduced pressure. The residue was subjected to flash silica gel chromatography to give $0.64 \mathrm{~g} \mathrm{(65 \% )} \mathrm{of} \mathrm{the} \mathrm{title} \mathrm{compound} \mathbf{4 5}$ as a colorless oil; ${ }^{1} \mathrm{H}-\mathrm{NMR}\left(400 \mathrm{MHz}, \mathrm{CDCl}_{3}\right) \delta 1.19(\mathrm{t}, 3 \mathrm{H}, J=7.4 \mathrm{~Hz}), 1.25(\mathrm{t}, 3 \mathrm{H}, J=6.8 \mathrm{~Hz})$, $1.26(\mathrm{t}, 3 \mathrm{H}, J=7.2 \mathrm{~Hz}), 1.63-1.77(\mathrm{~m}, 4 \mathrm{H}), 1.86(\mathrm{~m}, 2 \mathrm{H}), 2.32-2.42(\mathrm{~m}, 4 \mathrm{H}), 2.57(\mathrm{t}, 4 \mathrm{H}, J=$ $7.2 \mathrm{~Hz}), 2.60-2.74(\mathrm{~m}, 2 \mathrm{H}), 3.21(\mathrm{~d}, 1 \mathrm{H}, J=14.4 \mathrm{~Hz}), 3.34(\mathrm{~d}, 1 \mathrm{H}, J=14.4 \mathrm{~Hz}), 3.44$ (ddd, $2 \mathrm{H}, J=16.4,7.6$ and $6.4 \mathrm{~Hz}), 4.14(\mathrm{qd}, 2 \mathrm{H}, J=7.6$ and $1.6 \mathrm{~Hz}), 5.83(\mathrm{~d}, 1 \mathrm{H}, J=3.2 \mathrm{~Hz})$ and $5.88(\mathrm{~d}, 1 \mathrm{H}, J=3.2 \mathrm{~Hz}) ;{ }^{13} \mathrm{C}-\mathrm{NMR}\left(100 \mathrm{MHz}, \mathrm{CDCl}_{3}\right) \delta 12.4,14.3,14.5,21.5,21.7,22.5$, $25.9,26.7,26.8,30.6,33.3,47.4,61.2,104.4,105.5,129.5,144.7,153.4,156.3,167.3$ and 169.0; HRMS Calcd. for $\mathrm{C}_{22} \mathrm{H}_{33} \mathrm{NO}_{4} \mathrm{~S}: 407.2130$. Found: 407.2127 .

\section{2-\{(2-Ethanesulfinylacetyl)-[3-(5-ethyl-furan-2-yl)propyl]amino\}cyclohex-1-enecarboxylic Acid Ethyl Ester (47)}

To a solution of $0.6 \mathrm{~g}(1.5 \mathrm{mmol})$ of the above sulfide $45 \mathrm{in} 15 \mathrm{~mL}$ of a $20 \%$ aqueous methanol solution was added $0.7 \mathrm{~g}(3.0 \mathrm{mmol})$ of sodium periodate. After stirring for $15 \mathrm{~h}$ at room temperature, water was added and the solution was extracted with chloroform. The chloroform extracts were dried over $\mathrm{MgSO}_{4}$, filtered and concentrated under reduced pressure. The crude product was purified using flash silica gel chromatography to give $0.4 \mathrm{~g}(62 \%)$ of sulfoxide 47 as a colorless oil; ${ }^{1} \mathrm{H}-\mathrm{NMR}\left(400 \mathrm{MHz}, \mathrm{CDCl}_{3}\right) \delta 1.18(\mathrm{t}, 3 \mathrm{H}, J=7.8 \mathrm{~Hz}), 1.24(\mathrm{~m}, 3 \mathrm{H})$, $1.37(\mathrm{t}, 3 \mathrm{H}, J=7.8 \mathrm{~Hz}), 1.67(\mathrm{~m}, 3 \mathrm{H}), 2.81(\mathrm{~m}, 3 \mathrm{H}), 2.12-2.24(\mathrm{~m}, 1 \mathrm{H}), 2.33(\mathrm{~m}, 2 \mathrm{H}), 2.48$ $(\mathrm{m}, 1 \mathrm{H}), 2.55(\mathrm{~m}, 4 \mathrm{H}), 2.84(\mathrm{~m}, 1 \mathrm{H}), 3.12(\mathrm{~m}, 1 \mathrm{H}), 3.30-3.54(\mathrm{~m}, 2 \mathrm{H}), 3.67(\mathrm{dd}, 1 \mathrm{H}, \mathrm{J}=6.0$ and $3.9 \mathrm{~Hz}), 3.85(\mathrm{dd}, 1 \mathrm{H}, \mathrm{J}=14.4$ and $3.9 \mathrm{~Hz}), 4.14(\mathrm{dq}, 2 \mathrm{H}, J=18.6$ and $7.2 \mathrm{~Hz}), 5.82(\mathrm{~d}$, $1 \mathrm{H}, J=3.0 \mathrm{~Hz})$, and $5.85(\mathrm{~d}, 1 \mathrm{H}, J=3.0 \mathrm{~Hz}) ;{ }^{13} \mathrm{C}-\mathrm{NMR}\left(100 \mathrm{MHz}, \mathrm{CDCl}_{3}\right) \delta 6.5,6.8,12.3$, 14.3, 21.5, 22.3, 25.8, 26.5, 26.6, 30.6, 30.9, 46.5, 46.8, 47.1, 61.3, 61.4, 104.4, 105.6, 130.8, 
130.9, 143.3, 143.6, 152.9, 153.0, 156.3, 163.9, 164.4 and 166.9; HRMS Calcd. for $\mathrm{C}_{22} \mathrm{H}_{33} \mathrm{NO}_{5} \mathrm{~S}:$ 423.2079. Found: 423.2083.

\section{1,2-Furanyl Fused Ethyl 7-oxo-8-(phenylthio)dodecahydroazepino[1,2-I]-indole-8a- carboxylate (49)}

To a solution of $0.24 \mathrm{~g}(0.6 \mathrm{mmol})$ of sulfoxide $47 \mathrm{in} 6 \mathrm{~mL}$ of $\mathrm{CH}_{2} \mathrm{Cl}_{2}$ at $0{ }^{\circ} \mathrm{C}$ was added 0.13 $\mathrm{g}(0.6 \mathrm{mmol})$ of trifluoroacetic anhydride. After stirring for $10 \mathrm{~min}$ at $0{ }^{\circ} \mathrm{C}, 0.15 \mathrm{~mL}$ of trifluoroacetic acid was added and the mixture was allowed to warm to room temperature over $2 \mathrm{~h}$. The solution was concentrated under reduced pressure and the residue was subjected to flash silica gel chromatography to give $0.09 \mathrm{~g}(40 \%)$ of the title compound as a clear oil; ${ }^{1} \mathrm{H}$ NMR $\left(600 \mathrm{MHz}, \mathrm{CDCl}_{3}\right) \delta 0.99(\mathrm{t}, 3 \mathrm{H}, J=6.6 \mathrm{~Hz}), 1.17(\mathrm{t}, 3 \mathrm{H}, J=7.8 \mathrm{~Hz}), 1.26(\mathrm{t}, 3 \mathrm{H}, J=$ $7.8 \mathrm{~Hz}), 1.43(\mathrm{~m}, 1 \mathrm{H}), 1.62(\mathrm{~m}, 3 \mathrm{H}), 1.92(\mathrm{~m}, 3 \mathrm{H}), 2.11(\mathrm{~m}, 1 \mathrm{H}), 2.30(\mathrm{~m}, 2 \mathrm{H}), 2.50(\mathrm{q}, 2 \mathrm{H}$, $J=7.8 \mathrm{~Hz}), 2.71(\mathrm{~m}, 3 \mathrm{H}), 2.85(\mathrm{~m}, 1 \mathrm{H}), 2.94(\mathrm{~m}, 1 \mathrm{H}), 3.52(\mathrm{~s}, 1 \mathrm{H}), 3.89(\mathrm{~m}, 2 \mathrm{H}), 4.22(\mathrm{dt}, 1 \mathrm{H}$, $J=13.8$ and $4.8 \mathrm{~Hz})$ and $5.97(\mathrm{~s}, 1 \mathrm{H}) ;{ }^{13} \mathrm{C}-\mathrm{NMR}\left(100 \mathrm{MHz}, \mathrm{CDCl}_{3}\right) \delta 12.3,13.7,15.2,20.8$, 20.9, 21.3, 24.5, 26.4, 29.1, 37.0, 39.7, 51.7, 57.6,61.1,64.0, 105.0, 105.1, 121.9, 148.1, 155.3, 171.4 and 172.8; HRMS Calcd. for $\mathrm{C}_{22} \mathrm{H}_{31} \mathrm{NO}_{4} \mathrm{~S}$ : 405.1974. Found: 405.1977.

\section{3-Ethylsulfanyl-1-(3-furan-2-ylpropyl)-2-oxo-1,2,3,4,5,6-hexahydroindole-3a-carboxylic Acid Ethyl Ester (51)}

To a solution of $2.0 \mathrm{~g}$ of 3-(furan-2-yl)-propylamine ${ }^{33}(16.0 \mathrm{mmol})$ in $80 \mathrm{~mL}$ toluene was added 2-oxo-cyclohexane-carboxylic acid ethyl ester $(2.7 \mathrm{~g}, 16 \mathrm{mmol})$ and the solution was heated at reflux for $15 \mathrm{~h}$ using a condenser and Dean-Stark trap. After cooling to rt, powdered $4 \AA$ molecular sieves $(16 \mathrm{~g})$ was added and the mixture was chilled to $0{ }^{\circ} \mathrm{C}$. A solution of (ethylsulfanyl)acetyl chloride (prepared from $1.2 \mathrm{~g}(17.6 \mathrm{mmol})$ of ethylsufanyl acetic acid) in $35 \mathrm{~mL}$ of toluene was slowly added. The solution was allowed to slowly warm to rt and was stirred for an additional $15 \mathrm{~h}$ at $25{ }^{\circ} \mathrm{C}$. The solution was filtered through a pad of Celite and concentrated under reduced pressure. The residue was subjected to flash silica gel chromatography to provide $2.8 \mathrm{~g}$ (46\%) of 2-[(2-ethylsulfanylacetyl)-(3-furan-2-yl-propyl) amino-cyclohex-1-ene-carboxylicacid ethyl ester as a thick oil; ${ }^{1} \mathrm{H}-\mathrm{NMR}\left(\mathrm{CDCl}_{3}, 400 \mathrm{MHz}\right)$ $\delta 1.20(\mathrm{t}, 3 \mathrm{H}, J=5.6 \mathrm{~Hz}), 1.22(\mathrm{t}, 3 \mathrm{H}, J=7.6 \mathrm{~Hz}), 1.64(\mathrm{~m}, 4 \mathrm{H}), 1.85(\mathrm{~m}, 2 \mathrm{H}), 2.30-2.50(\mathrm{~m}$ $4 \mathrm{H}), 2.59(\mathrm{t}, 2 \mathrm{H}, J=7.6 \mathrm{~Hz}), 2.65(\mathrm{~m}, 2 \mathrm{H}), 3.17(\mathrm{~m}, 1 \mathrm{H}), 3.30(\mathrm{~m}, 1 \mathrm{H}), 3.41(\mathrm{~m}, 2 \mathrm{H}), 4.10$ (qd, $2 \mathrm{H}, J=7.2$ and $1.2 \mathrm{~Hz}$ ), $5.94(\mathrm{dd}, 1 \mathrm{H}, J=3.2$ and $0.8 \mathrm{~Hz}), 6.22(\mathrm{dd}, 1 \mathrm{H}, J=3.2$ and 2.0 $\mathrm{Hz}), 7.24(\mathrm{~d}, 1 \mathrm{H}, \mathrm{J}=0.8 \mathrm{~Hz}) ;{ }^{13} \mathrm{C}-\mathrm{NMR}\left(\mathrm{CDCl}_{3}, 100 \mathrm{MHz}\right) \delta 13.9,14.2,21.4,22.1,25.5,26.2$, 26.3, 26.4, 30.3, 33.0, 46.9, 60.8, 105.0, 110.0, 129.3, 140.7, 144.3, 155.0, 167.0, and 168.7; HRMS Calcd. for $\left[\mathrm{C}_{20} \mathrm{H}_{29} \mathrm{NO}_{4} \mathrm{~S}\right]^{+}: 379.1817$. Found: 379.1829 .

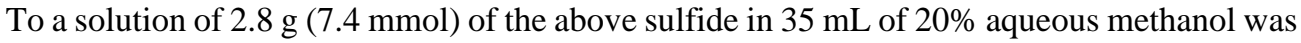
added $2.4 \mathrm{~g}(11.0 \mathrm{mmol})$ of sodium periodate. After stirring at $\mathrm{rt}$ for $15 \mathrm{~h}$, water was added and the solution was extracted with chloroform. The extracts were dried with $\mathrm{MgSO}_{4}$, filtered and concentrated under reduced pressure. The residue was subjected to flash silica gel chromatography to give $2.3 \mathrm{~g}$ (78\%) of 2-[(2-ethanesulfinylacetyl)-(3-furan-2-yl-propyl) amino]-cyclohex-1-enecarboxylic acid ethyl ester (50) as a colorless oil; ${ }^{1} \mathrm{H}-\mathrm{NMR}\left(\mathrm{CDCl}_{3}\right.$, $400 \mathrm{MHz}) \delta 1.19(\mathrm{~m}, 3 \mathrm{H}), 1.32(\mathrm{t}, 3 \mathrm{H}, J=7.6 \mathrm{~Hz}), 1.62-1.81(\mathrm{~m}, 6 \mathrm{H}), 2.19(\mathrm{~m}, 1 \mathrm{H}), 2.29(\mathrm{~m}$, $2 \mathrm{H}), 2.45(\mathrm{~m}, 1 \mathrm{H}), 2.56(\mathrm{t}, 2 \mathrm{H}, J=7.6 \mathrm{~Hz}), 2.79(\mathrm{~m}, 1 \mathrm{H}), 3.06(\mathrm{~m}, 1 \mathrm{H}), 3.26-3.52(\mathrm{~m}, 2 \mathrm{H})$, $3.64(\mathrm{~m}, 1 \mathrm{H}), 3.82(\mathrm{~m}, 1 \mathrm{H}), 4.10(\mathrm{dq}, 2 \mathrm{H}, J=13.2$ and $7.6 \mathrm{~Hz}), 5.94(\mathrm{~d}, 1 \mathrm{H}, J=3.2 \mathrm{~Hz}), 6.20$ $(\mathrm{dd}, 1 \mathrm{H}, J=2.8$ and $0.8 \mathrm{~Hz})$, and $7.23(\mathrm{~d}, 1 \mathrm{H}, J=1.2 \mathrm{~Hz}) ;{ }^{13} \mathrm{C}-\mathrm{NMR}\left(\mathrm{CDCl}_{3}, 100 \mathrm{MHz}\right) \delta 6.4$, 6.7, 14.1, 21.3, 22.1, 25.5, 26.3, 26.4, 26.5, 30.5, 30.8, 46.4, 46.6, 46.8, 54.7, 56.5, 61.1, 61.3, 105.1, 110.1, 130.7, 130.8, 140.9, 143.2, 143.3, 154.9, 163.9, 164.3, 166.6, and 166.7; HRMS Calcd. for $\left[\mathrm{C}_{20} \mathrm{H}_{29} \mathrm{NO}_{5} \mathrm{~S}\right]^{+}$: 395.1766. Found: 395.1767.

To a solution of $0.28 \mathrm{~g}(0.7 \mathrm{mmol})$ of sulfoxide $\mathbf{5 0}$ dissolved in $40 \mathrm{~mL}$ of benzene was added $0.7 \mathrm{~g}$ of 10 -camphorsulfonic acid $(2.8 \mathrm{mmol})$. The solution was heated at reflux for $30 \mathrm{~min}$ and 
then cooled to room temperature. The benzene solution was washed with a saturated sodium bicarbonate solution, dried with $\mathrm{MgSO}_{4}$, and concentrated under reduced pressure. The crude product was subjected to flash silica gel chromatography to give $0.18 \mathrm{~g}(70 \%)$ of $\mathbf{5 1}$ as a colorless oil; IR (thin film) $1725,1680,1404$ and $1180 \mathrm{~cm}^{-1 ; 1} \mathrm{H}-\mathrm{NMR}\left(\mathrm{CDCl}_{3}, 400 \mathrm{MHz}\right) \delta$ $1.20(\mathrm{~m}, 3 \mathrm{H}), 1.25(\mathrm{t}, 3 \mathrm{H}, J=7.2 \mathrm{~Hz}), 1.40(\mathrm{~m}, 1 \mathrm{H}), 1.82-1.92(\mathrm{~m}, 4 \mathrm{H}), 2.04-2.33(\mathrm{~m}, 2 \mathrm{H})$, $2.72(\mathrm{~m}, 5 \mathrm{H}), 3.22(\mathrm{~m}, 1 \mathrm{H}), 3.47(\mathrm{~m}, 1 \mathrm{H}), 3.82(\mathrm{~m}, 1 \mathrm{H}), 4.13(\mathrm{~m}, 2 \mathrm{H}), 4.94(\mathrm{t}, 1 \mathrm{H}, J=3.6 \mathrm{~Hz})$, $6.02(\mathrm{~d}, 1 \mathrm{H}, J=3.2 \mathrm{~Hz}), 6.25(\mathrm{dd}, 1 \mathrm{H}, J=3.2$ and $1.6 \mathrm{~Hz})$, and $7.28(\mathrm{~d}, 1 \mathrm{H}, J=0.8 \mathrm{~Hz}) ;{ }^{13} \mathrm{C}-$ NMR $\left(\mathrm{CDCl}_{3}, 100 \mathrm{MHz}\right) \delta 14.2,14.7,19.6,22.7,25.0,25.7,27.1,30.5,39.6,54.3,55.4,61.6$, 100.7, 105.4, 110.3, 137.5, 141.1, 155.2, 170.3 and 171.1; HRMS Calcd. for $\mathrm{C}_{20} \mathrm{H}_{27} \mathrm{NO}_{4} \mathrm{~S}[\mathrm{M}$ $+\mathrm{H}^{+}$]: 378.1739. Found: 378.1729 .

\section{4-Bromo-5-(3-hydroxypropyl)furan-2-carboxylic Acid Methyl Ester}

To a solution of $2.8 \mathrm{~g}$ (10 mmol) of 2,3-dibromo-5-carbomethox vfuran ${ }^{42}$ in $50 \mathrm{~mL}$ of DMF was added $0.7 \mathrm{~g}$ ( $12 \mathrm{mmol})$ of allyl alcohol, $0.08 \mathrm{~g}(0.2 \mathrm{mmol})$ of palladium (II) acetate, $2.3 \mathrm{~g}$ (10 mmol) of benzyltriethylammonium chloride, and $2.1 \mathrm{~g}(25 \mathrm{mmol})$ of sodium bicarbonate. The reaction vessel was purged with Argon, sealed and heated to $80^{\circ} \mathrm{C}$ for $2 \mathrm{~h}$. After cooling to $25^{\circ} \mathrm{C}$, the solution was filtered through a pad of Celite and water was added to the filtrate. The solution was extracted with ether and the combined ether extracts were washed with brine, dried over $\mathrm{MgSO}_{4}$, filtered and concentrated under reduced pressure. The crude product was subjected to flash silica gel chromatography to give $1.9 \mathrm{~g}$ (73\%) of methyl 4-bromo-5-(3oxopropyl)furan-2-carboxylate as a colorless oil: ${ }^{1} \mathrm{H}-\mathrm{NMR}\left(\mathrm{CDCl}_{3}, 400 \mathrm{MHz}\right) \delta 2.90(\mathrm{t}, 2 \mathrm{H}$, $J=6.8 \mathrm{~Hz}), 3.04(\mathrm{t}, 2 \mathrm{H}, J=7.6 \mathrm{~Hz}), 3.87(\mathrm{~s}, 3 \mathrm{H}), 7.11(\mathrm{~s}, 1 \mathrm{H})$, and $9.83(\mathrm{~s}, 1 \mathrm{H}) ;{ }^{13} \mathrm{C}-\mathrm{NMR}$ $\left(\mathrm{CDCl}_{3}, 100 \mathrm{MHz}\right) \delta 19.4,41.0,52.3,98.7,121.4,143.2,155.6,158.4$, and 199.7. The aldehyde was used immediately in the next step.

A $0.6 \mathrm{~g}(2.3 \mathrm{mmol})$ sample of the above aldehyde was dissolved in methanol $(12 \mathrm{~mL})$ and the solution was cooled to $0^{\circ} \mathrm{C}$. To this solution was added $0.1 \mathrm{~g}(2.5 \mathrm{mmol})$ of sodium borohydride in several portions. After stirring for $30 \mathrm{~min}$, the reaction mixture was quenched with water and extracted with ethyl acetate. The extracts were dried over $\mathrm{MgSO}_{4}$, filtered and concentrated under reduced pressure. The crude product was subjected to flash silica gel chromatography to give $0.46 \mathrm{~g}$ (77\%) of the title alcohol as a clear oil; IR (thin film) 3418, 2951, 1734, 1533 and $1199 \mathrm{~cm}^{-1 ; 1} \mathrm{H}-\mathrm{NMR}\left(\mathrm{CDCl}_{3}, 300 \mathrm{MHz}\right) \delta 1.82(\mathrm{bs}, 1 \mathrm{H}), 1.94(\mathrm{p}, 2 \mathrm{H}, J=6.3 \mathrm{~Hz}), 2.84$ $(\mathrm{t}, 2 \mathrm{H}, J=7.2 \mathrm{~Hz}), 3.67(\mathrm{t}, 2 \mathrm{H}, J=6.3 \mathrm{~Hz}), 3.87(\mathrm{~s}, 3 \mathrm{H})$, and $7.11(\mathrm{~s}, 1 \mathrm{H}) ;{ }^{13} \mathrm{C}-\mathrm{NMR}$ $\left(\mathrm{CDCl}_{3}, 75 \mathrm{MHz}\right) \delta 23.1,30.4,52.3,61.7,98.4,121.4,142.9,157.6$, and 158.6; HRMS Calcd. for $\mathrm{C}_{9} \mathrm{H}_{11} \mathrm{BrO}_{4}$ : 261.9841. Found: 261.9842.

\section{5-(3-Azidopropyl)-4-bromo-furan-2-carboxylic Acid Methyl Ester (53)}

To a solution of $0.46 \mathrm{~g}(1.7 \mathrm{mmol})$ of the above alcohol in $8.7 \mathrm{~mL}$ of $\mathrm{CH}_{2} \mathrm{Cl}_{2}$ at $0{ }^{\circ} \mathrm{C}$ was added $0.2 \mathrm{~g}$ ( $1.9 \mathrm{mmol})$ of methanesulfonyl chloride followed by $0.35 \mathrm{~g}(3.5 \mathrm{mmol})$ of triethylamine. After stirring for $30 \mathrm{~min}$ at $25^{\circ} \mathrm{C}$, water was added and the mixture was extracted with $\mathrm{CH}_{2} \mathrm{Cl}_{2}$ The combined organic layer was dried over $\mathrm{MgSO}_{4}$, filtered and concentrated under reduced pressure. The resulting mesylate was thoroughly dried and was taken up in $2 \mathrm{~mL}$ of DMF and $0.12 \mathrm{~g}(1.9 \mathrm{mmol})$ of sodium azide was added. The mixture was stirred at $45^{\circ} \mathrm{C}$ for $15 \mathrm{~h}$ and then water was added. The solution was extracted with ether and the ether extracts were washed with brine. The organic layer was dried over $\mathrm{MgSO}_{4}$, filtered and concentrated under reduced pressure. The crude azide was subjected to flash silica gel chromatography to give $0.47 \mathrm{~g} \mathrm{(93 \% )} \mathrm{of} \mathrm{azide} \mathbf{5 3}$ as a yellow oil; IR (thin film) 2951, 2108, 1739, and 1315 $\mathrm{cm}^{-1 ; 1} \mathrm{H}-\mathrm{NMR}\left(\mathrm{CDCl}_{3}, 400 \mathrm{MHz}\right) \delta 1.96(\mathrm{p}, 2 \mathrm{H}, J=7.2 \mathrm{~Hz}), 2.82(\mathrm{t}, 2 \mathrm{H}, J=7.2 \mathrm{~Hz}), 3.33(\mathrm{t}$, $2 \mathrm{H}, J=6.8 \mathrm{~Hz}), 3.87(\mathrm{~s}, 3 \mathrm{H})$, and $7.12(\mathrm{~s}, 1 \mathrm{H}) ;{ }^{13} \mathrm{C}-\mathrm{NMR}\left(\mathrm{CDCl}_{3}, 100 \mathrm{MHz}\right) \delta 23.8,26.9$, 50.6, 52.2, 98.8, 121.3, 143.2, 156.4, and 158.5; FAB HRMS Calcd. for $\left[\left(\mathrm{C}_{9} \mathrm{H}_{10} \mathrm{BrN}_{3} \mathrm{O}_{3}\right)\right.$ $\left.+\mathrm{Li}^{+}\right]$: 294.0066. Found: 294.0070. 


\section{4-Bromo-5-[3-(3a-methyl-2-oxo-2,3,3a,4,5,6-hexahydroindol-1-yl)propyl]-furan-2-carboxylic Acid Methyl Ester (56)}

To a solution of the above azide $\mathbf{5 3}(1.0 \mathrm{mmol})$ in xylene $(5 \mathrm{~mL})$ in a microwave reaction tube was added tributyl-phosphine $(1.0 \mathrm{mmol})$. The mixture was stirred for $1 \mathrm{~h}$ at room temperature, the solvent was removed under reduced pressure and $5 \mathrm{~mL}$ of xylene was added to the initially formed iminophosphorane $\mathbf{5 4}$ and this was followed by the addition of keto acid $\mathbf{1 4}$ (1 mmol). The reaction mixture was subjected to microwave irradiation at $180^{\circ} \mathrm{C}$ for $10 \mathrm{~min}$. The solution was concentrated under reduced pressure and the crude mixture was chromatographed on a silica gel column to give hexahydroindolinone $\mathbf{5 6}(63 \%)$ as a colorless oil ${ }^{1} \mathrm{H}-\mathrm{NMR}(300 \mathrm{MHz}$, $\left.\mathrm{CDCl}_{3}\right) \delta 1.19(\mathrm{~s}, 3 \mathrm{H}), 1.52(\mathrm{~m}, 1 \mathrm{H}), 1.76-2.20(\mathrm{~m}, 7 \mathrm{H}), 2.25(\mathrm{~s}, 2 \mathrm{H}), 2.72(\mathrm{t}, 2 \mathrm{H}, J=7.8 \mathrm{~Hz})$, $3.24(\mathrm{~m}, 1 \mathrm{H}), 3.68(\mathrm{~m}, 1 \mathrm{H}), 3.87(\mathrm{~s}, 3 \mathrm{H}), 4.74(\mathrm{t}, 1 \mathrm{H}, J=3.6 \mathrm{~Hz})$, and $7.10(\mathrm{~s}, 1 \mathrm{H}) ;{ }^{13} \mathrm{C}-\mathrm{NMR}$ $\left(75 \mathrm{MHz}, \mathrm{CDCl}_{3}\right) \delta 18.5,22.8,24.3,24.8,26.3,34.1,36.4,38.5,46.4,52.2,97.5,98.4,121.4$, 143.0, 145.5, 156.9, 158.5, and 174.0; HRMS Calcd. for $\mathrm{C}_{18} \mathrm{H}_{22} \mathrm{BrNO}_{4}$ : 395.0733. Found: 395.0742

\section{7-Carbomethoxy-7-(2-ethoxy-2-oxoethyl)-1,4-dioxaspiro[4,5]decan-8-one(57)}

To a solution of $2.8 \mathrm{~g}(70 \mathrm{mmol})$ of $\mathrm{NaH}\left(60 \%\right.$ in mineral oil) in $200 \mathrm{~mL}$ of $\mathrm{THF}$ at $0^{\circ} \mathrm{C}$ was added $10 \mathrm{~g}$ (64 mmol) of 1,4-dioxaspiro[4,5]decan-8-one (62) under $\mathrm{N}_{2}$ and the mixture was stirred vigorously for $30 \mathrm{~min}$. The cold bath was removed and dimethyl carbonate $(5.4 \mathrm{~mL}, 64$ $\mathrm{mmol}$ ) was added dropwise. Upon complete addition, the solution was placed in an oil bath and heated at reflux for $24 \mathrm{~h}$. A saturated $\mathrm{NH}_{4} \mathrm{Cl}$ solution was then added and the reaction mixture was extracted with EtOAc. The combined organic layer was dried over $\mathrm{MgSO}_{4}$, filtered and concentrated under reduced pressure. Purification of the crude product using flash silica gel chromatography gave $6.3 \mathrm{~g}$ (48\%) of the enol tautomer of 7-carbomethoxy-8-hydroxy-1,4dioxaspiro[4,5]decan-7-ene; ${ }^{1} \mathrm{H}-\mathrm{NMR}\left(\mathrm{CDCl}_{3}, 400 \mathrm{MHz}\right) \delta 1.79(\mathrm{t}, 2 \mathrm{H}, J=7.2 \mathrm{~Hz}), 2.41$ (s, $2 \mathrm{H}), 2.45(\mathrm{tt}, 2 \mathrm{H}, J=7.2$ and $1.2 \mathrm{~Hz}), 3.69(\mathrm{~s}, 3 \mathrm{H}), 3.92-3.98(\mathrm{~m}, 4 \mathrm{H})$ and $12.10(\mathrm{~s}, 1 \mathrm{H})$. This compound was used in the next step without any further purification.

To a solution of $0.3 \mathrm{~g}(7.5 \mathrm{mmol})$ of $\mathrm{NaH}\left(60 \%\right.$ in mineral oil) in $30 \mathrm{~mL}$ of $\mathrm{THF}$ at $0^{\circ} \mathrm{C}$ was added $1.3 \mathrm{~g}(6.2 \mathrm{mmol})$ of the above compound under $\mathrm{N}_{2}$ and the mixture was stirred for 30 $\mathrm{min}$. The cold bath was removed and ethyl bromo-acetate $(0.9 \mathrm{~mL}, 8.1 \mathrm{mmol})$ was added dropwise. The solution was stirred at $25^{\circ} \mathrm{C}$ for $2 \mathrm{~h}$. Water was added and the solution was extracted with EtOAc. The combined organic layer was dried over $\mathrm{MgSO}_{4}$, filtered and concentrated under reduced pressure. The crude mixture was subjected to flash silica gel chromatography to give $1.5 \mathrm{~g}(81 \%)$ of $\mathbf{5 7}$ as a colorless oil; IR (neat) 1730, 1717, 1375, 1305, $1195,1167,1136$ and $1033 \mathrm{~cm}^{-1 ; 1} \mathrm{H}-\mathrm{NMR}\left(400 \mathrm{MHz}, \mathrm{CDCl}_{3}\right) \delta 1.21(\mathrm{t}, 3 \mathrm{H}, J=7.2 \mathrm{~Hz}), 1.94-$ $2.09(\mathrm{~m}, 2 \mathrm{H}), 2.12(\mathrm{~d}, 1 \mathrm{H}, J=13.6 \mathrm{~Hz}), 2.49$ (d, $1 \mathrm{H}, J=16.4 \mathrm{~Hz}), 2.52(\mathrm{~d}, 1 \mathrm{H}, J=14.0 \mathrm{~Hz}$ ), 2.48-2.55 (m, 1H), 2.77 (d, 1H, $J=16.0 \mathrm{~Hz}), 3.08$ (ddd, $1 \mathrm{H}, J=15.2,13.2$ and $7.2 \mathrm{~Hz}$ ), 3.73 $(\mathrm{s}, 3 \mathrm{H}), 3.88-4.01(\mathrm{~m}, 4 \mathrm{H})$ and $4.08(\mathrm{dq}, 2 \mathrm{H}, J=7.2$ and 2.8$) ;{ }^{13} \mathrm{C}-\mathrm{NMR}\left(100 \mathrm{MHz}, \mathrm{CDCl}_{3}\right)$ $\delta 14.2,34.7,37.5,39.7,42.0,52.9,56.7,60.8,64.6,65.0,106.6,170.5,172.5$ and 205.9.

\section{Methyl 1 -(3-(5-methylfuran-2-yl)propyl)-5,5-(1 -oxa-4-oxa butylene)-2,3,3a,4,5,6- hexahydro-1 $\mathrm{H}$-indole-2-one-3a-carboxylate (58)}

To a solution of $0.35 \mathrm{~g}(1.2 \mathrm{mmol})$ of diester 57 in $2 \mathrm{~mL}$ of xylene in a microwave reaction tube was added $0.24 \mathrm{~g}(1.8 \mathrm{mmol})$ of 3-(5-methylfuran-2-yl)propan-1-amine (22). The vessel was sealed and subjected to microwave irradiation at $180{ }^{\circ} \mathrm{C}$ for $20 \mathrm{~min}$. After removal of the solvent under reduced pressure, the crude residue was purified by flash silica gel chromatography to give $0.24 \mathrm{~g}(55 \%)$ of $\mathbf{5 8}$ as a colorless oil; IR (neat) 1726, 1677, 1406, 1311, $1288,1170,1139$ and $1118 \mathrm{~cm}^{-1 ; 1} \mathrm{H}-\mathrm{NMR}\left(400 \mathrm{MHz}, \mathrm{CDCl}_{3}\right) \delta 1.74(\mathrm{~d}, 1 \mathrm{H}, J=13.2 \mathrm{~Hz})$, $1.88-2.00(\mathrm{~m}, 2 \mathrm{H}), 2.23(\mathrm{~d}, 3 \mathrm{H}, \mathrm{J}=0.8 \mathrm{~Hz}), 2.48-2.53(\mathrm{~m}, 1 \mathrm{H}), 2.62$ (q, $2 \mathrm{H}, \mathrm{J}=7.6 \mathrm{~Hz}), 2.55-$ $2.71(\mathrm{~m}, 2 \mathrm{H}), 2.75(\mathrm{dd}, 1 \mathrm{H}, \mathrm{J}=13.2$ and $1.2 \mathrm{~Hz}), 3.22-3.28(\mathrm{~m}, 1 \mathrm{H}), 3.66(\mathrm{~s}, 3 \mathrm{H}), 3.80(\mathrm{dt}, 1 \mathrm{H}$, $J=14.0$ and $7.6 \mathrm{~Hz}), 3.84-3.91(\mathrm{~m}, 1 \mathrm{H}), 3.92-4.00(\mathrm{~m}, 4 \mathrm{H}), 4.96(\mathrm{t}, 1 \mathrm{H}, J=3.6 \mathrm{~Hz}), 5.83(\mathrm{dd}$, 
$1 \mathrm{H}, J=2.8$ and $0.8 \mathrm{~Hz})$ and $5.88(\mathrm{~d}, 1 \mathrm{H}, J=2.8 \mathrm{~Hz}) ;{ }^{13} \mathrm{C}-\mathrm{NMR}\left(100 \mathrm{MHz}, \mathrm{CDCl}_{3}\right) \delta 13.7$, 25.3, 25.7, 35.3, 39.3, 39.4, 42.9, 48.6, 52.9, 64.7, 64.8, 97.7, 106.1, 107.4, 139.3, 150.6, 153.4, 172.1 and 174.6; HRMS Calcd. for $\mathrm{C}_{20} \mathrm{H}_{25} \mathrm{NO}_{6}\left[\mathrm{M}+\mathrm{H}^{+}\right]$: 376.1715 . Found: 376.1757 .

\section{Methyl 1 -(4,7-dioxooctyl)-2,5-dioxo-2,3,3a,4,5,6-hexahydro-1 H-indole-3a-carboxylate (60)}

To a solution of $0.13 \mathrm{~g}(0.36 \mathrm{mmol})$ of tetrahydroindolinone 58 in $7 \mathrm{~mL}$ of $\mathrm{CH}_{2} \mathrm{Cl}_{2}$ was added trifluoroacetic acid $(82 \mu \mathrm{L}, 1.1 \mathrm{mmol})$. The mixture was stirred at $\mathrm{rt}$ for $24 \mathrm{~h}$ and then heated at reflux for another $24 \mathrm{~h}$. The solvent was removed under reduced pressure and the crude product was purified by flash silica gel chromatography to give $0.08 \mathrm{~g}(67 \%)$ of a pale yellow oil which was identified as methyl 1 -(4,7-dioxooctyl)-2,5-dioxo-2,3,3a,-4,5,6-hexahydro-1 $H$-indole-3a-carboxylate (60) on the basis of its spectral data; IR (neat) 1719, 1678, 1609, 1411, 1367 and $1225 \mathrm{~cm}^{-1 ; 1} \mathrm{H}-\mathrm{NMR}\left(400 \mathrm{MHz}, \mathrm{CDCl}_{3}\right) \delta 1.73-1.82(\mathrm{~m}, 1 \mathrm{H}), 1.84-1.90(\mathrm{~m}, 1 \mathrm{H})$, $2.17(\mathrm{~s}, 3 \mathrm{H}), 2.42(\mathrm{~d}, 1 \mathrm{H}, \mathrm{J}=16.2 \mathrm{~Hz}), 2.46(\mathrm{~d}, 1 \mathrm{H}, \mathrm{J}=16.8 \mathrm{~Hz}), 2.46-2.57(\mathrm{~m}, 2 \mathrm{H}), 2.59-2.78$ $(\mathrm{m}, 4 \mathrm{H}), 2.96-3.12(\mathrm{~m}, 2 \mathrm{H}), 3.04(\mathrm{dd}, 2 \mathrm{H}, \mathrm{J}=16.8$ and $8.4 \mathrm{~Hz}), 3.36(\mathrm{ddd}, 1 \mathrm{H}, J=14.4,7.8$ and $6.0 \mathrm{~Hz}), 3.65(\mathrm{dt}, 1 \mathrm{H}, J=14.4$ and $7.8 \mathrm{~Hz}), 3.72(\mathrm{~s}, 3 \mathrm{H})$ and $5.17(\mathrm{dd}, 1 \mathrm{H}, J=6.6$ and 2.4 $\mathrm{Hz}) ;{ }^{13} \mathrm{C}-\mathrm{NMR}\left(100 \mathrm{MHz}, \mathrm{CDCl}_{3}\right) \delta 20.4,30.1,36.3,37.0,37.2,39.2,39.3,40.1,46.4,47.6$, 53.5, 95.7, 140.1, 171.8, 173.1, 205.7, 207.4 and 208.7; HRMS Calcd. For $\mathrm{C}_{18} \mathrm{H}_{23} \mathrm{NO}_{6}[\mathrm{M}$ $+\mathrm{H}^{+}$]: 350.1604. Found: 350.1596 .

The minor fraction isolated from the column contained $0.01 \mathrm{~g}(11 \%)$ of methyl 1 -(3-(5methylfuran-2-yl)propyl)-2,5-dioxo-2,3,3a,4,5,6-hexahydro- $1 H$-indole-3a-carboxylate (61) as a pale yellow oil; IR (neat) 1731, 1614, 1414, 1209, 1177 and $735 \mathrm{~cm}^{-1 ; 1} \mathrm{H}-\mathrm{NMR}$ (400 $\left.\mathrm{MHz}, \mathrm{CDCl}_{3}\right) \delta 1.83-1.93(\mathrm{~m}, 2 \mathrm{H}), 2.23(\mathrm{~s}, 3 \mathrm{H}), 2.40(\mathrm{~d}, 1 \mathrm{H}, J=16.4 \mathrm{~Hz}), 2.46(\mathrm{~d}, 1 \mathrm{H}, J=$ $16.8 \mathrm{~Hz}), 2.59(\mathrm{t}, 2 \mathrm{H}, \mathrm{J}=7.6 \mathrm{~Hz}), 2.92-3.14(\mathrm{~m}, 4 \mathrm{H}), 3.35-3.42(\mathrm{~m}, 1 \mathrm{H}), 3.71(\mathrm{~s}, 3 \mathrm{H}), 3.69-$ $3.76(\mathrm{~m}, 1 \mathrm{H}), 5.02(\mathrm{dd}, 1 \mathrm{H}, \mathrm{J}=6.0$ and $2.4 \mathrm{~Hz}), 5.84(\mathrm{~s}, 1 \mathrm{H})$ and $5.87(\mathrm{~d}, 1 \mathrm{H}, \mathrm{J}=2.4 \mathrm{~Hz}) ;{ }^{13} \mathrm{C}-$ NMR $\left(100 \mathrm{MHz}, \mathrm{CDCl}_{3}\right) \delta 13.7,25.1,25.4,37.0,39.6,40.1,46.4,47.6,53.5,95.4,106.1$, 106.2, 140.3, 150.7, 153.0, 171.7, 173.1 and 205.7; HRMS Calcd. for $\mathrm{C}_{18} \mathrm{H}_{21} \mathrm{NO}_{5}\left[\mathrm{M}+\mathrm{H}^{+}\right]$: 332.1498. Found: 332.1496.

\section{7a-Hydroxy-1-(3-(5-methylfuran-2-yl)propyl)-5,5-(1-oxa-4-oxa-butylene)-hexahydro-1 $\mathrm{H}$ - indol-2(3H)-one (64)}

To a solution of $1.8 \mathrm{mmol}$ lithium diisopropylamine in $60 \mathrm{~mL}$ of THF at $-78{ }^{\circ} \mathrm{C}$ was added a dropwise solution of $0.2 \mathrm{~g}(1.4 \mathrm{mmol})$ of 1,4-dioxaspiro[4,5]decan-8-one $(\mathbf{6 2})$ in $11 \mathrm{~mL}$ of THF under $\mathrm{N}_{2}$. The mixture was stirred at $-78^{\circ} \mathrm{C}$ for $30 \mathrm{~min}$ and then a solution of $0.4 \mathrm{~g}(1.2$ $\mathrm{mmol}$ ) of 2-iodo- $\mathrm{N}$-(3-(5-methylfuran-2-yl)propyl)acetamide (63) in $14 \mathrm{~mL}$ of THF was added dropwise to the reaction mixture over a 3 min interval. The solution was stirred for an additional $5 \mathrm{~min}$ at $-78^{\circ} \mathrm{C}$ and was allowed to warm to rt over $30 \mathrm{~min}$. The reaction mixture was quenched with water and extracted with $\mathrm{CH}_{2} \mathrm{Cl}_{2}$ - The organic layer was dried over $\mathrm{Na}_{2} \mathrm{SO}_{4}$ and concentrated under reduced pressure. The crude reaction mixture was purified by flash silica gel chromatography to give $0.27 \mathrm{~g}(70 \%)$ of $\mathbf{6 4}$ as a colorless oil; IR (neat) $3354,1671,1570$, $1433,1368,1125,1023$ and $785 \mathrm{~cm}^{-1 ; 1} \mathrm{H}-\mathrm{NMR}\left(400 \mathrm{MHz}, \mathrm{CDCl}_{3}\right) \delta 1.41(\mathrm{dd}, 1 \mathrm{H}, J=14.0$ and $8.4 \mathrm{~Hz}), 1.50(\mathrm{ddd}, 1 \mathrm{H}, J=13.6,9.6$ and $3.6 \mathrm{~Hz}), 1.66-1.72(\mathrm{~m}, 1 \mathrm{H}), 1.76-1.96(\mathrm{~m}, 4 \mathrm{H})$, 2.03 (ddd, $1 \mathrm{H}, J=14.4,9.6$ and $4.0 \mathrm{~Hz}$ ), 2.13 (dd, $1 \mathrm{H}, J=16.4$ and $5.2 \mathrm{~Hz}$ ), 2.18 (s, 3H), 2.29$2.36(\mathrm{~m}, 1 \mathrm{H}), 2.53-2.60(\mathrm{~m}, 3 \mathrm{H}), 3.12(\mathrm{ddd}, 1 \mathrm{H}, J=14.0,9.6$ and $6.4 \mathrm{~Hz}), 3.30(\mathrm{ddd}, 1 \mathrm{H}, J=$ 14.0, 9.6 and $5.6 \mathrm{~Hz}), 3.88(\mathrm{~s}, 4 \mathrm{H}), 4.24(\mathrm{brs}, 1 \mathrm{H}), 5.77(\mathrm{dd}, 1 \mathrm{H})$ and $5.82(\mathrm{~d}, 1 \mathrm{H}, J=3.2$ $\mathrm{Hz}) ;{ }^{13} \mathrm{C}-\mathrm{NMR}\left(100 \mathrm{MHz}, \mathrm{CDCl}_{3}\right) \delta 13.6,25.9,27.8,30.7,31.0,36.1,36.2,38.6,40.7,64.3$, 64.4, 89.9, 105.7, 106.0, 107.9, 150.3, 153.5 and 175.3; HRMS Calcd. for $\mathrm{C}_{18} \mathrm{H}_{25} \mathrm{NO}_{5}[\mathrm{M}$ $+\mathrm{H}^{+}$]: 336.1812. Found: 336.1806 .

\section{1,2-Furanyl Fused Octahydroazepino[1,2- $]$ indole-7,10(1H,8H)-dione (65)}

To a solution of $0.2 \mathrm{~g}(0.72 \mathrm{mmol})$ of aminol $64 \mathrm{in} 7 \mathrm{~mL}$ of $\mathrm{CH}_{2} \mathrm{Cl}_{2}$ at $0{ }^{\circ} \mathrm{C}$ was added trifluoroacetic acid $(0.11 \mathrm{~mL}, 1.4 \mathrm{mmol})$. The reaction mixture was stirred at $\mathrm{rt}$ for $24 \mathrm{~h}$ and 
then a saturated $\mathrm{NaHCO}_{3}$ solution was added and the resulting mixture was extracted with $\mathrm{CH}_{2} \mathrm{Cl}_{2}$ - The combined organic layer was washed with a saturated $\mathrm{NaHCO}_{3}$ solution, dried over $\mathrm{Na}_{2} \mathrm{SO}_{4}$ and concentrated under reduced pressure. The crude mixture was purified by flash silica gel chromatography to give $0.06 \mathrm{~g}(30 \%)$ of $\mathbf{6 5}$ as a pale yellow oil); IR (neat) 1716, 1678, 1407, 1269 and $730 \mathrm{~cm}^{-1 ;}{ }_{1} \mathrm{H}-\mathrm{NMR}\left(400 \mathrm{MHz}, \mathrm{CDCl}_{3}\right) \delta 1.87-1.95(\mathrm{~m}, 2 \mathrm{H}), 2.04(\mathrm{dd}$, $1 \mathrm{H}, J=17.6$ and $4.0 \mathrm{~Hz}), 2.13-2.30(\mathrm{~m}, 3 \mathrm{H}), 2.20(\mathrm{~s}, 3 \mathrm{H}), 2.32-2.36(\mathrm{~m}, 1 \mathrm{H}), 2.40(\mathrm{~d}, 1 \mathrm{H}$, $J=15.6$ and $7.2 \mathrm{~Hz}), 2.62-2.72(\mathrm{~m}, 2 \mathrm{H}), 2.78(\mathrm{ddd}, 1 \mathrm{H}, J=14.4,9.2$ and $5.6 \mathrm{~Hz}), 2.84-2.97$ $(\mathrm{m}, 3 \mathrm{H}), 4.30(\mathrm{dt}, 1 \mathrm{H}, J=14.4$ and $4.8 \mathrm{~Hz})$ and $5.81(\mathrm{~s}, 1 \mathrm{H}) ;{ }^{13} \mathrm{C}-\mathrm{NMR}\left(100 \mathrm{MHz}, \mathrm{CDCl}_{3}\right) \delta$ $13.5,25.4,26.8,32.2,35.4,37.1,37.2,39.9,43.2,62.6,104.9,126.6,149.1,150.3,173.4$ and 210.2; HRMS Calcd. for $\mathrm{C}_{16} \mathrm{H}_{19} \mathrm{NO}_{3}\left[\mathrm{M}+\mathrm{H}^{+}\right]$: 274.1444. Found: 274.1440 .

The other minor compound that was isolated from the chromatographic column consisted of $0.02 \mathrm{~g}(9 \%)$ of the corresponding ketal of $\mathbf{6 5}$ as a colorless oil; ${ }^{1} \mathrm{H}-\mathrm{NMR}\left(400 \mathrm{MHz}, \mathrm{CDCl}_{3}\right)$ $\delta 1.49(\mathrm{dd}, 1 \mathrm{H}, J=13.6$ and $12.0 \mathrm{~Hz}), 1.51(\mathrm{td}, 1 \mathrm{H}, J=13.6$ and $4.0 \mathrm{~Hz}), 1.63$ (ddd, $1 \mathrm{H}, J=$ $13.2,6.4$ and $4.0 \mathrm{~Hz}), 1.78(\mathrm{ddd}, 1 \mathrm{H}, J=13.6,6.4$ and $2.8 \mathrm{~Hz}), 1.82-1.88(\mathrm{~m}, 1 \mathrm{H}), 1.92(\mathrm{~d}, 1 \mathrm{H}$, $J=16.0 \mathrm{~Hz}), 1.96-2.06(\mathrm{~m}, 2 \mathrm{H}), 2.15(\mathrm{dt}, 1 \mathrm{H}, J=15.2$ and $4.0 \mathrm{~Hz}), 2.18(\mathrm{~s}, 3 \mathrm{H}), 2.42(\mathrm{dd}, 1 \mathrm{H}$, $J=16.0$ and $6.8 \mathrm{~Hz}), 2.55-2.61(\mathrm{~m}, 1 \mathrm{H}), 2.66(\mathrm{dd}, 2 \mathrm{H}, J=6.0$ and $5.6 \mathrm{~Hz}), 2.99(\mathrm{dt}, 1 \mathrm{H}, J=$ 14.4 and $5.6 \mathrm{~Hz}), 3.90-4.00(\mathrm{~m}, 4 \mathrm{H}), 4.31(\mathrm{ddd}, 1 \mathrm{H}, J=14.4,8.8$ and $6.0 \mathrm{~Hz})$ and $5.85(\mathrm{~s}$, $1 \mathrm{H}) ;{ }^{13} \mathrm{C}-\mathrm{NMR}\left(100 \mathrm{MHz}, \mathrm{CDCl}_{3}\right) \delta 13.6,25.7,26.1,30.5,31.2,37.1,37.5,38.1,38.9,62.1$, 64.5, 64.7, 105.3, 107.7, 126.6, 149.6, 150.8 and 176.0.

\section{Supplementary Material}

Refer to Web version on PubMed Central for supplementary material.

\section{Acknowledgements}

This research was supported by the National Institutes of Health (GM 0539384) and the National Science Foundation (CHE-0450779). MDR wishes to express her appreciation to the NIH for a Ruth L. Kirchstein Predoctoral Fellowship. We wish to thank Dr. Ayse Daut Ozdemir for some preliminary experiments in developing the aza-Wittig reactions used to prepare the starting furanyl substituted tetrahydroindolinones.

\section{References and Notes}

1. Pictet A, Spengler T. Ber Dtsch Chem Ges 1911;44:2030.

2. Decker H, Becker P. Justus Liebigs Ann Chem 1913;395:342.

3. For reviews, see: (a) Czerwinski KM, Cook JM. Adv Heterocycl Nat Prod Synth 1996;3:217. (b) Cox ED, Cook JM. Chem Rev 1995;95:1797. (c) Waldmann H. Synlett 1995:133. (d) Rozwadowska MD. Heterocycles 1994;39:903. (e) Badia D, Dominguez E, Lete E, Villa MJ. Trends Heterocycl Chem 1991;2:1. (f) Ungemach F, Cook JM. Heterocycles 1978;9:1089.(g) ClaretPABartonDOllisWEComprehensive Organic ChemistryPergomonOxford19794209(h) GenslerWJElderfieldRCHeterocyclic CompoundsWileyNew York19524353 (i) Whaley WM, Govindachari TR. Org React 1951;6:151.

4. Brown, RT. Indoles. Saxton, JE., editor. Wiley-lnterscience; New York: 1983. Part 4 (b) Bentley KW. Nat Prod Rep 2004;21:395. [PubMed: 15162226] and references cited therein

5. Strong Brönsted acids are most commonly employed to promote the Pictet-Spengler reaction, see: (a) Dunetz JR, Ciccolini RP, Fröling M, Paap SM, Allen AJ, Holmes AB, Tester JW, Danheiser RL. Chem Commun 2005:4465. (b) Nakamura S, Tanaka M, Taniguchi T, Uchiyama M, Ohwada T. Org Lett 2003;5:2087. [PubMed: 12790535] (c) Kuo F-M, Tseng M-C, Yen Y-H, Chu Y-H. Tetrahedron 2004;60:12075.

6. Yokoyama A, Ohwada T, Shudo K. J Org Chem 1999;64:611.

7. (a) Cox ED, Hamaker LK, Li J, Yu P, Czerwinski KM, Deng L, Bennett DW, Cook JM. J Org Chem 1997;62:44. [PubMed: 11671363] (b) Czarnocki Z, MacLean DB, Szarek WA. Can J Chem 1986;64:2205. (c) Czarnocki Z, Suh D, MacLean DB, Hultin PG, Szarek WA. Can J Chem 1992;70:1555. (d) Czarnocki Z, Mieczkowsi JB, Kiegiel J, Arazny Z. Tetrahedron: Asymmetry 
1995;6:2899. (e) Waldmann H, Schmidt G, Henke H, Burkard M. Angew Chem Int Ed Engl 1995;34:2402. (f) Schmidt G, Waldmann H, Hanke H, Burkard M. Chem Eur J 1996;2:1566. (g) Gremmen C, Willemse B, Wanner MJ, Koomen G-J. Org Lett 2000;2:1955. [PubMed: 10891200] (h) Gremmen C, Wanner MJ, Koomen G-J. Tetrahedron Lett 2001;42:8885. (i) Tsuji R, Nakagawa M, Nishida A. Tetrahedron:Asymmetry 2003;14:177.

8. Taylor MS, Jacobsen EN. J Am Chem Soc 2004;126:10558. [PubMed: 15327311]

9. Seayad J, Seayad AM, List B. J Am Chem Soc 2006;128:1086. [PubMed: 16433519]

10. (a) Lee HI, Cassidy MP, Rashatasakhon P, Padwa A. Org Lett 2003;5:5067. [PubMed: 14682766]

(b) Padwa A, Lee HI, Rashatasakhon P, Rose M. J Org Chem 2004;69:8209. [PubMed: 15549789]

(c) Cassidy MP, Özdemir AD, Padwa A. Org Lett 2005;7:1339. [PubMed: 15787501]

11. Dyke, SF.; Quessy, SN. The Alkaloids. Rodrigo, RGA., editor. 18. Academic Press; New York: 1981. p. 1-98.Chawla, AS.; Kapoor, VK. The Alkaloids: Chemical and Biological Perspectives. Pelletier, SW., editor. 9. Pergamon; 1995. p. 86-153.

12. Deulofeu, V. Curare and Curarelike Agents. Bovet, D.; Bovet-Nitti, F.; Marini-Bettolo, GB., editors. Elsevier; Amsterdam: 1959. p. 163

13. Tsuda, Y.; Sano, T. The Alkaloids. Cordell, GA., editor. 48. Academic Press; San Diego: 1996. p. 249-337.

14. Kawasaki T, Onoda N, Watanabe H, Kitahara T. Tetrahedron Lett 2001;42:8003.

15. (a) Wang Q, Padwa A. Org Lett 2006;8:601. [PubMed: 16468721] (b) Kim G, Kim JH, Lee KY. J Org Chem 2006;71:2185. [PubMed: 16497016] (c) Parsons AF, Williams DA. Tetrahedron 2000;56:7217. (d) Belleau B. J Am Chem Soc 1953;75:5765. (e) Mondon A, Hansen KF. Tetrahedron Lett 1960;1:5. (f) Ishibashi H, Sato T, Takahashi M, Hayashi M, Ikeda M. Heterocycles 1988;27:2787. (g) Tsuda Y, Hosoi S, Ishida K, Sangai M. Chem Pharm Bull 1994;42:204. (h) Cassayre J, Quiclet-Sire B, Saunier J-B, Zard SZ. Tetrahedron Lett 1998;39:8995. (i) Rigby JH, Deur C, Heeg MJ. Tetrahedron Lett 1999;40:6887. (j) Toyao A, Chikaoka S, Takeda Y, Tamura O, Muraoka O, Tanabe G, Ishibashi H. Tetrahedron Lett 2001;42:1729. (k) Miranda LD, Zard SZ. Org Lett 2002;4:1135. [PubMed: 11922801] (I) Allin SM, James SL, Elsegood MRJ, Martin WP. J Org Chem 2002;67:9464. [PubMed: 12492356] (m) Toda J, Niimurea Y, Takeda K, Sano T, Tsuda Y. Chem Pharm Bull 1998;46:906. (n) Jousse C, Demaële D. Eur J Org Chem 1999:909.

16. (a) Danishefsky SJ, Panek JS. J Am Chem Soc 1987;109:917. (b) Ahmed-Schofield R, Mariano PS. J Org Chem 1987;52:1478. (c) Irie H, Shibata K, Matsuno K, Zhang Y. Heterocycles 1989;29:1033. (d) Kawasaki T, Onoda N, Watanabe H, Kitahara T. Tetrahedron Lett 2001;42:8003.

17. (a) Wasserman HH, Amici RM. J Org Chem 1989;54:5843. (b) Sano T, Toda J, Kashiwaba N, Ohshima T, Tsuda Y. Chem Pharm Bull 1987;35:479. (c) Tsuda Y, Hosoi S, Katagiri N, Kaneko C, Sano T. Heterocycles 1992;33:497.

18. Curtis, WM. The Student's Flora of Tasmania, Part 1. Tasmanian Government Printer; Hobart: 1956. p. 6 (b) Bick IRC, Bremner JB, Razak A, Thuc LV. Experientia 1980;36:1135. (c) Panichanun S, Bick IRC. Tetrahedron 1984;40:2685.

19. For some earlier examples of furan-terminated $\mathrm{N}$-acyliminium ion initiated cyclizations, see: Tanis SP, Deaton MV, Dixon LA, McMills MC, Raggon JW, Collins MA. J Org Chem 1998;63:6914. [PubMed: 11672313]

20. Maryanoff BE, Zhang HC, Cohen JH, Turchi IJ, Maryanoff CA. Chem Rev 2004;104:1431. [PubMed: 15008627]

21. (a) Wilkens HJ, Traxler F. Helv Chim Acta 1975;58:1512. (b) Mondon A, Hansen KF, Boehme K, Faro HP, Nestler HJ, Vilhuber HG, Böttcher K. Chem Ber 1970;103:615. (c) Mondon A, Nestler HJ. Chem Ber 1979;112:1329. (d) Dean RT, Rapoport HA. J Org Chem 1978;43:4183.

22. The $\beta$-erythroidine skeleton has been prepared by an oxidative degradation of the aromatic ring (ring A) in erythrinas as the key step; see: Isobe K, Mohri K, Itoh Y, Toyokawa Y, Takeda N, Taga J, Hosoi S, Tsuda Y. Chem Pharm Bull 1992;40:2632.

23. Bentley KW. Nat Prod Rep 2001;18:148. [PubMed: 11336286]

24. Staudinger H, Meyer J. Helv Chim Acta 1919;2:635.

25. (a) Wamhoff H, Richardt G, Stölben S. Adv Heterocycl Chem 1995;64:159. (b) Eguchi S, Matsushita Y, Yamashita K. Org Prep Proced Int 1992;24:209. (c) Barluenga J, Palacios F. Org Prep Proced Int 1991;23:1. (d) Fresneda PM, Molina P. Synlett 2004:1. 
26. (a) Molina P, Vilaplana MJ. Synthesis 1994:1917. (b) Gusari NI. Russ Chem Rev (Engl Transl) 1991;60:146.

27. Padwa A, Gunn DE, Osterhout MH. Synthesis 1997:1353.

28. (a) Padwa A, Hennig R, Kappe CO, Reger TS. J Org Chem 1998;63:1144. (b) Padwa A, Kappe CO, Reger TS. J Org Chem 1996;61:4888. (c) Padwa A, Heidelbaugh TM, Kuethe JT, McClure MS. J Org Chem 1998;63:6778. [PubMed: 11672292]

29. Padwa A, Heidelbaugh TM, Kuethe JT, McClure MS, Wang Q. J Org Chem 2002;67:5928. [PubMed: 12182624]

30. Denmark, SE. Comprehensive Organic Synthesis. Trost, BM.; Fleming, I., editors. 5. Pergamon Press; Oxford: 1991. p. 751-784.

31. While our studies were in progress, a related report appeared in the literature, see: Gao S, Tu YQ, Hu X, Wang S, Hua R, Jiang Y, Zhao Y, Fan X, Zhang S. Org Lett 2006;8:2373. [PubMed: 16706529]

32. Asselin AA, Number LG, Dobson TA, Komlossy J, Martel RR. J Med Chem 1976;19:787. [PubMed: 950647]

33. Jung ME, Miller SJ. Heterocycles 1990;30:839.

34. Sorm F, Brandejs J. Coll Czec Chem Comm 1947;12:444.

35. Pleninger H, Castro CE. Chem Ber 1954;87:1760.

36. Shuikin NI, Petrov AD, Glukhovtsev VG, Bel'skii IF, Skobtsova GE. Isvestiya Akademii Nauk SSSR, Seriya Khim 1964;9:1682.

37. Wedler C, Schick H. J Prakt Chem 1993;335:410.

38. Kel'in AV, Gevorgyan V. J Org Chem 2002;67:95. [PubMed: 11777444]

39. López-Rodríguez ML, Viso A, Ortega-Gutiérrez S, Fowler CJ, Tiger G, de Lago E, Fernández-Ruiz J, Ramos JA. J Med Chem 2003;46:1512. [PubMed: 12672252]

40. Herz W. J Am Chem Soc 1953;75:483.

41. Snieckus V, Bhandari KS. Tetrahedron Lett 1969;39:3375.

42. Chadwick DJ, Chambers J, Meakins GD, Snowden RL. J Chem Soc, Perkin Trans 1 1973:1766. 


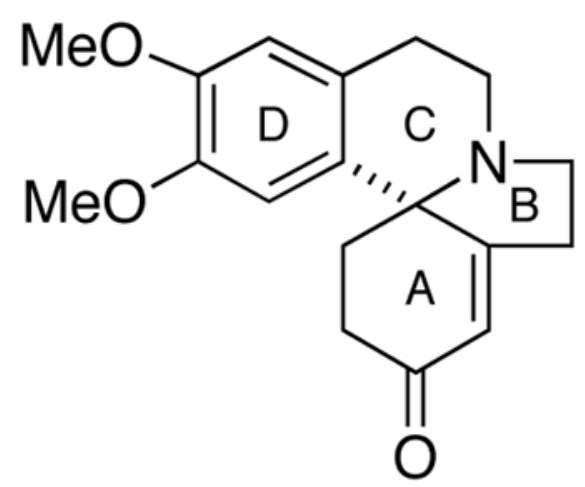

7; 3-Demethoxyerythratidinone

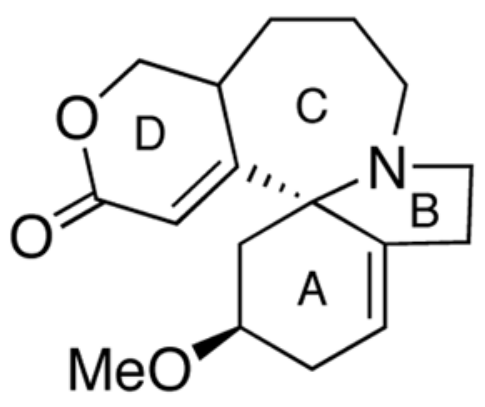

\section{9; Phellibiline}

Figure 1.

Representative Erythrinan and Homoerythrinan Alkaloids

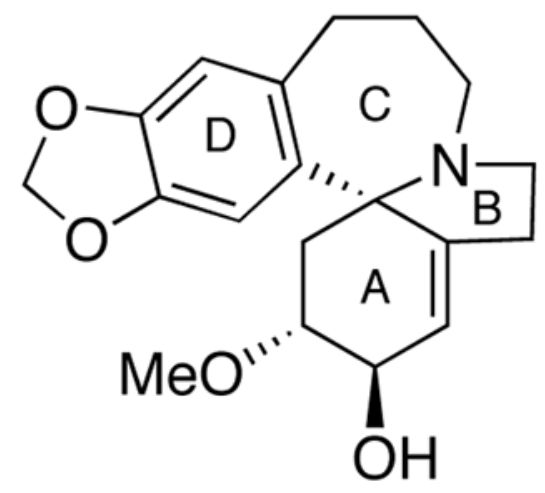

8; Schelhammerine<smiles>[2H]O[C@H]1CC=C2CCN3CCCc4oc(C(O)(O)O[Na])cc4[C@@]23C1</smiles>

10; Selaginoidine 

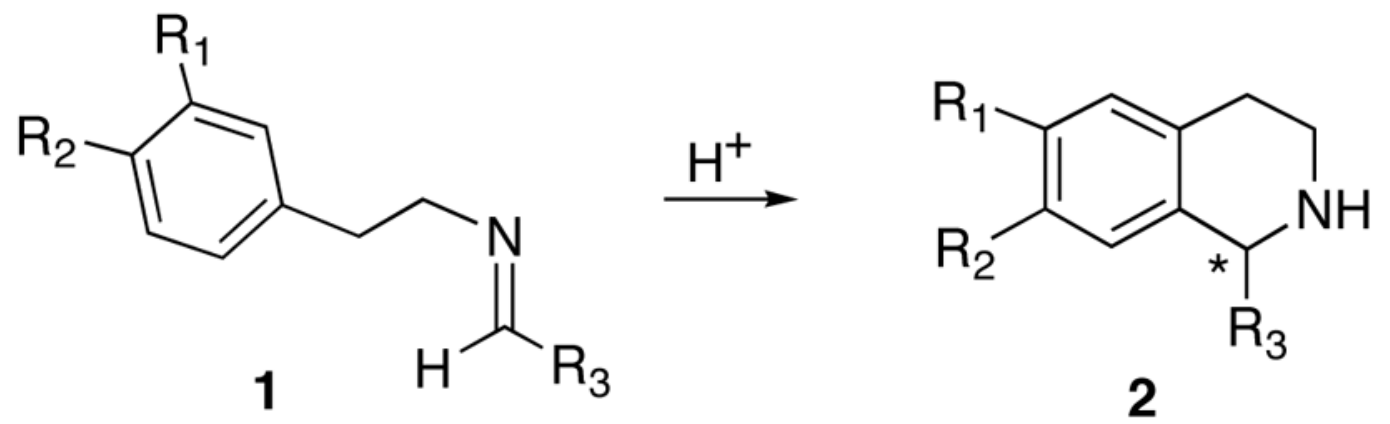

Scheme 1.

Pictet-Spengler Cyclization 


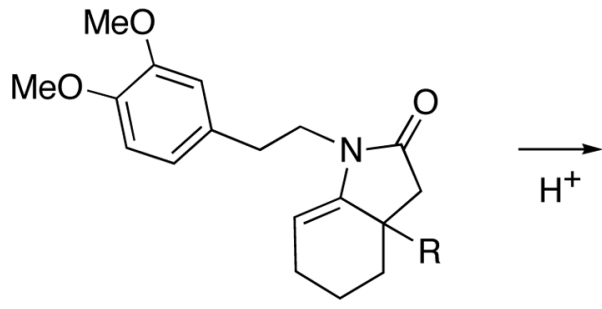

3a; $\mathrm{R}=\mathrm{Me}$

3b; $\mathrm{R}=\mathrm{SPh}$

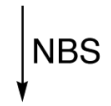<smiles>CCC1=CC(=O)c2cc(OC)c(OC)cc2[C@@]12CCCCC2Br</smiles>

5<smiles>[R]C12CCCC[C@@]13c1cc(OC)c(OC)cc1CCN3C(=O)C2</smiles>

$4 ; \mathrm{R}=\mathrm{Me}$

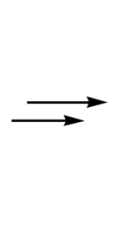<smiles>COc1cc2c(cc1OC)[C@@]1(CC=C[C@H](OC)C1)C1=CC(=O)N2CC1</smiles>

6; ( \pm -Erysotramidine

Scheme 2.

NBS Promoted Cyclization Reaction 
<smiles>[R]c1cc2c(o1)CCCN1CCCC21CC[C@H](CC)OC</smiles>

10; $\mathrm{R}_{1}=\mathrm{CO}_{2} \mathrm{Me}$<smiles>[R7]c1ccc(CCCN)o1</smiles>

13<smiles>[R]c1ccc(CCCN2C(=O)CC3([R2])CCCC=C23)o1</smiles>

11<smiles>C1CCCC1</smiles><smiles>[R2]C1(CC(=O)O)CCCCC1=O</smiles>

Scheme 3.

Retrosynthetic Analysis Toward Selaginoidine (10) 


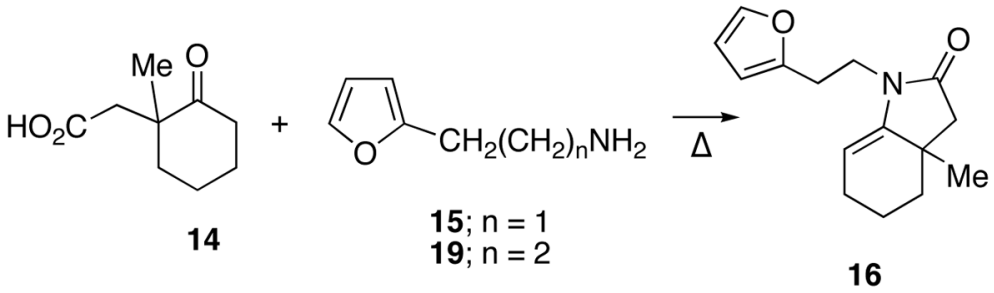

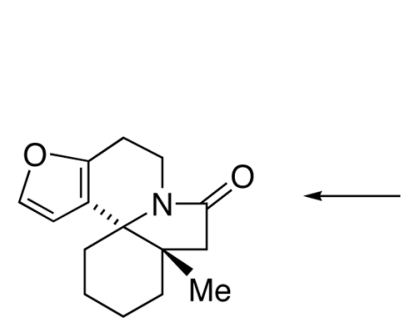

18

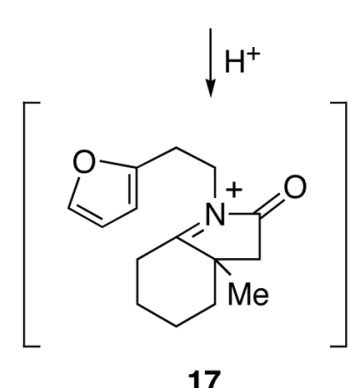

Scheme 4.

Mechanism of the Acid Promoted Cyclization 
<smiles>C[C@@]12CCCCC1(c1ccc(CCCN3C(=O)C[C@@]4(C)CCCCC34c3ccc(CCCN4C(=O)C[C@]5(C)CCCC[C@@]45C)o3)o1)[PH+]C2</smiles>

20

Scheme 5.

Dimer Formation Using an Unsubstitued Furan 
<smiles>Cc1ccc(CCCN)o1</smiles>

22<smiles>Cc1cc2c(o1)CCCN1C(=O)C[C@]3(COCc4ccccc4)CCCC[C@]21C3</smiles>

25<smiles>CCOC(=O)CC1(C(=O)OCc2ccccc2)CCCCC1=O</smiles>

23<smiles>Cc1ccc(CCCN2C(=O)CC3(C(=O)OCc4ccccc4)CCCC=C23)o1</smiles>

24

Scheme 6.

Seven-Membered Ring Skeleton 


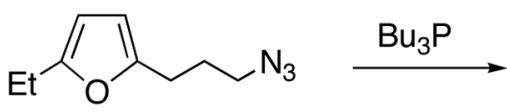

26<smiles>CCCCCC[Sb](C)(C)=NCCCc1ccc(CC)o1</smiles>

27<smiles>CC1(CC(=O)O)CCCCC1=O</smiles><smiles>CCc1ccc(CCCN2C(=O)CC3(C)CCCC=C23)o1</smiles>

29<smiles>C[PH+]</smiles>

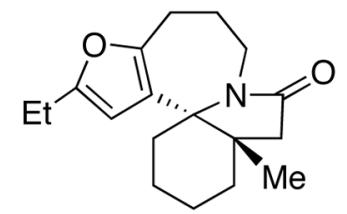

30

Scheme 7.

Use of Iminophosphoranes for the Synthesis of Tetrahydroindolinones 

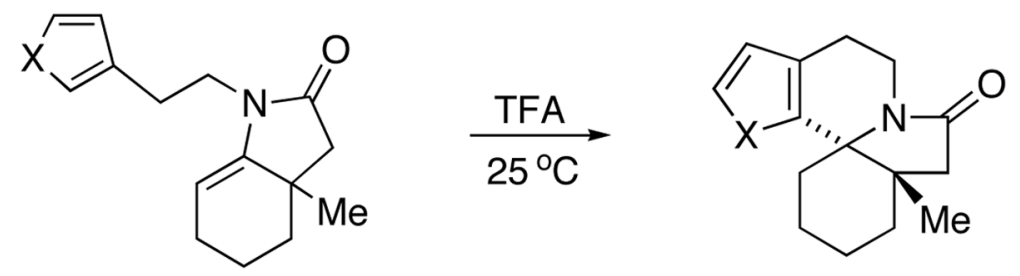

$31 ; X=O$
$33 ; X=S$

32; $\mathrm{X}=\mathrm{O}$

$34 ; X=S$<smiles></smiles>

35; $\mathrm{X}=\mathrm{S}$

37; $\mathrm{X}=\mathrm{NH}$

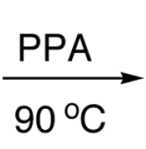<smiles></smiles>

36; $X=S$

38; $\mathrm{X}=\mathrm{NH}$

Scheme 8.

Acid-Promoted Cyclization of Various Heteroaromatic Systems 
<smiles>CC1(CC(=O)[OH2+])CCCCC1=O</smiles>

14<smiles>NCCc1c[nH]c2ccccc12</smiles>

39<smiles>NCCc1cc2ccccc2[nH]1</smiles>

41<smiles>CC(=O)N1CCc2c([nH]c3ccccc23)[C@]12CCCCC2(C)C</smiles>

40<smiles></smiles>

42

Scheme 9.

Cyclization of Indolyl Substituted Systems 


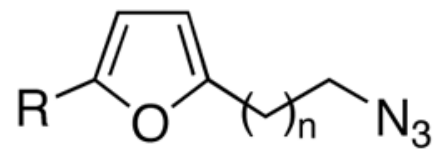<smiles>CCOC(=O)C1CCCCC1=O</smiles>

43; $\mathrm{n}=1 ; \mathrm{R}=\mathrm{H}$ $26 ; n=2 ; R=E t$

$\mathrm{EtSCH} \mathrm{COCl}_{2}$

44; $\mathrm{n}=1 ; \mathrm{R}=\mathrm{H}$ 45; $\mathrm{n}=2 ; \mathrm{R}=\mathrm{Et}$

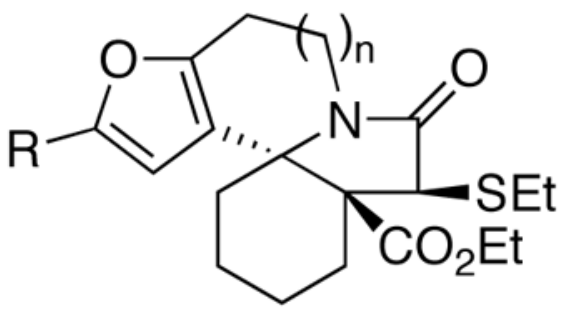

$\frac{\text { TFAA }}{\text { TFA }}$

48; $\mathrm{n}=1 ; \mathrm{R}=\mathrm{H}$

49; $n=2 ; R=E t$<smiles>[R]c1ccc(CCN(C(=O)C[Si](CC)O[Na])C2=C(C(=O)OCC)CCCC2)o1</smiles>

46; $\mathrm{n}=1 ; \mathrm{R}=\mathrm{H}$ 47; $n=2 ; R=E t$

Scheme 10.

Pummerer/Mannich Cyclizations 
<smiles>CCOC(=O)C1=C(N(CCCc2ccco2)C(=O)C[Sb](O)C[IH+])CCCC1</smiles>

50
??

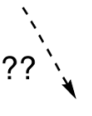<smiles>CCOC12CCCC=C1N(CCCc1ccco1)C(=O)C2[Si]CC</smiles>

51<smiles>CCOC(=O)C1(N2CCc3occc32)CCCCC1</smiles>

52

Scheme 11.

A Failed Pummerer/N-Acyliminium ion Cascade 
<smiles>COC(=O)c1cc(Br)c(CCCN=[Pb])o1</smiles>

53

54<smiles>CC1(CC(=O)O)CCCCC1=O</smiles>

14<smiles>COCc1cc(Br)c(CCCN2C(=O)CC3(C)CCCC=C23)o1</smiles>

56<smiles>COCc1cc(Br)c(CCCC2(C)CCCC(C)(CCC(=O)OC)C2)o1</smiles>

55

Scheme 12.

Synthesis of a Bromo Substituted Tetrahydroindolinone 


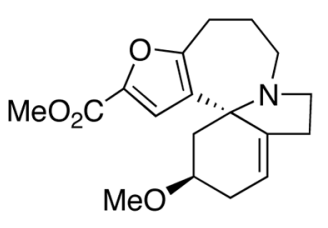

selaginoidine (10)<smiles>CCOC(=O)CC1(C(OC)OC)CC2(CCC1=O)OCCO2</smiles>

57<smiles>CC(=O)CCC(=O)CCCN1C(=O)CC2(OC(C)=O)CC(=O)CC=C12</smiles>

60<smiles>C1=CCCC1</smiles><smiles>CO[C@H]1CC2(CC[C@@]34c5cc(C)oc5CCCN3C(=O)C[C@H]24)OCCO1</smiles>

59<smiles>C1CCC1</smiles><smiles>COC12CC(=O)N(CCCc3ccc(C)o3)C1=CCC1(C2)OCCO1</smiles>

58<smiles>COC(=O)C12CC(=O)CC=C1N(CCCc1ccc(C)o1)C(=O)C2</smiles>

61

Scheme 13.

Tetrahydroindolinone Containing a 1,3-Dioxolanyl Group 


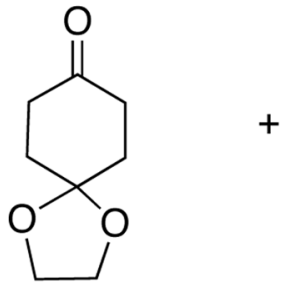

62<smiles>Cc1cc2c(o1)CCCN1CCC(=O)C[C@@H]2CC1=O</smiles>

$\stackrel{\text { TFA }}{\longleftarrow}$

65<smiles>Cc1ccc(CCCNC(=O)OI)o1</smiles>

63<smiles>[Mg][Mg]</smiles><smiles>Cc1ccc(CCCN2C(=O)CC3CC4(CCC32O)OCCO4)o1</smiles>

64

Scheme 14.

Successful Cyclization Leading to the Homoerythrina Skeleton 